\title{
Utjecaj zainteresiranosti i nepoticanog samoreguliranog učenja na krajnji ishod učenja građe i svojstva tla
}

\author{
Balažinec M. ${ }^{1}$, Radanović I. ${ }^{2}$, Sertić Perić M. ${ }^{2}$ \\ ${ }^{1}$ III. osnovna škola Varaždin, Trg Ivana Perkovca 35, Varaždin; ORCID: 0000-0001-9762-0668 \\ marina.barisic13@gmail.com \\ ${ }^{2}$ Sveučilište u Zagrebu, Prirodoslovno-matematički fakultet, Biološki odsjek, Rooseveltov $\operatorname{trg} 6$, Zagreb; \\ ORCID: 0000-0003-3239-0536, ORCID: 0000-0002-4744-7884
}

\section{SAŽETAK}

Za uspješno savladavanje gradiva pri poučavanju, neophodno je pobuditi interes učenika za kontekst poučavanja izborom prikladnih aktivnosti učenja. Pri tome je vrlo važan i odnos učenika prema učenju te način kako samostalno uče nakon početnog učenja u školi. Ovo istraživanje usmjereno je na ispitivanje povezanosti: (i) početne zainteresiranosti učenika za teme vezane uz tematsku cjelinu Tlo, (ii) strategija učenja koje učenici koriste tijekom učenja i (iii) uspjeha na pisanoj provjeri znanja provedenoj na kraju obrađene tematske cjeline Tlo. Istraživanje je provedeno u dva odjeljenja petog razreda III. Osnovne škole Varaždin na 43 učenika. Istraživanje je pokazalo kako su učenici u dobi od 11 godina izrazito zainteresirani za učenje tema vezanih uz Tlo te su učenici koji su slabije riješili ispit, kao i oni učenici koji su ga riješili vrlo uspješno na početku učenja, iskazali jednaku zainteresiranost za učenje o tlu. Učenici koji intuitivno samostalno sistematiziraju gradivo uz namjeru uočavanja povezivanja, prepoznaju primjenu svog znanja u aktivnostima poput projekata te imaju visoku intrinzičnu motivaciju za učenje Prirode i trude se biti uspješni na nastavi, čak i ako im se ne sviđa ono što uče. Za razliku od njih, učenici koji uspješno rješavaju samo zadatke reproduktivnog karaktera nisu skloni povezivanju svog znanja i često uče napamet. Također učenici usmjereni na reproduktivno učenje ne prepoznaju da aktivnosti provedene tijekom učenja i poučavanja mogu poslužiti kao osnova s kojom mogu povezati ranije obrađena znanja. Za potrebe poticanja učenika na razmišljanje i samoregulirajuće učenje, $s$ učenicima bi se trebale češće provoditi aktivnosti u kojima se traži argumentirano povezivanje stečenog znanja pri generiranju objašnjenja.

Ključne riječi: zainteresiranost učenika; samoregulirano učenje; učenje o tlu; građa i svojstva tla

\section{UVOD}

Interes je presudan za odabir postupaka i ustrajnost pri obradi i usporedbi određenih vrsta podataka, budući da je određen psihološkim stanjem koje uključuje usmjerenu pažnju, povećano kognitivno funkcioniranje, upornost i afektivnu uključenost (Hidi, 1990). Premda usmjeravanje pažnje i kognitivna uključenost zahtijevaju velik napor, aktivnosti za koje pojedinac ima interes čine se relativno lake $\mathbf{i}$ pristupačne (Hidi, 2000). Prema brojnim istraživanjima, interes snažno utječe na kognitivno i afektivno funkcioniranje pojedinaca (Hidi, 1990; Schiefele, 1991; Krapp, 1999). Već početkom 19. stoljeća njemački filozof Herbart prepoznao je da postoji bliska veza između interesa i učenja (Hidi, 1990). Početkom 20. stoljeća, Dewey (1913) je naglasio važnu ulogu zanimanja (interesa) za učenje, budući da je zanimanje za neku temu ili objekt rezultat interaktivnog procesa između pojedinca i njegove okoline. Za pozitivan ishod učenja vrlo je važan stupanj zainteresiranosti za nastavne sadržaje koje učenici uče (Dewey, 1916). Učenici zadatak moraju smatrati važnim, vrijednim, ali i zanimljivim (Pintrich i DeGroot, 1990), kako bi mu poklonili pažnju tijekom učenja. 
Osim što je pri poučavanju neophodno pobuditi interes učenika za kontekst poučavanja izborom prikladnih aktivnosti učenja, vrlo je važan odnos učenika prema učenju i način kako samostalno uče nakon početnog učenja u školi. Samoregulirajuće učenje je samostalno, svrhovito i trajno učenje $s$ ciljem poboljšanja znanja vještina i sposobnosti, koje se razvija pod utjecajem okruženja, misli, osjećaja, i ponašanja učenika (Juričić Devčić i sur, 2012). Sastoji se od tri glavne komponente: kognicije, metakognicije i motivacije (Pintrich i De Groot, 1990). Kognicija uključuje vještine potrebne za kodiranje i pamćenje informacija, metakognicija uključuje vještine koje omogućuju razumijevanje i promatranje vlastitog kognitivnog procesa; motivacija uključuje uvjerenja i stavove koji utječu na uporabu i razvoj kognitivnih i metakognitivnih vještina (Juričić Devčić i sur., 2012). Svaka od tih triju komponenti je potrebna, ali nije dovoljna za samoregulaciju učenja (Zimmerman, 2000). Prilikom samoreguliranog učenja, učenici postavljaju vlastite ciljeve učenja i onda upravljaju, prate, reguliraju i kontroliraju svoje spoznaje, motivaciju i ponašanje kako bi ostvarili te ciljeve (Wolters i sur, 2005). Učenici uspoređuju procese i rezultate svojih aktivnosti s ciljevima ili standardima koje su postavili, kako bi odredili treba li nastaviti s učenjem ili ga mijenjati (Zeidner i sur, 2005). Samoregulirajuće učenje je vrlo važan koncept i jedna od ključnih kompetencija u 21. stoljeću (Buljubašić-Kuzmanović, 2014). Zbog toga je u projektu Cjelovite kurikularne reforme (CKR) kao dio kurikuluma za osnovno i srednjoškolsko obrazovanje (Jokić i sur, 2016) izrađen kurikulum za međupredmetnu temu Učiti kako učiti za osnovne i srednje škole u Republici Hrvatskoj (Marušić i sur, 2016). Njegova je svrha omogućiti učenicima da razviju znanja i vještine upravljanja svojim učenjem i primjene odgovarajućih strategija u različitim situacijama učenja (NN 7/2019). Kognitivno učenje uključuje strategije ponavljanja, organizacije, elaboracije i kritičkog promišljanja, a usmjerene su na razumijevanje gradiva i rješavanje problema, pri čemu je samo ponavljanje površinsko, dok su ostale kategorije učenja dubinske (Vrkić i Vlahović Štetić, 2013). Za razliku od kognitivnih strategija, metakognitivne strategije zahtijevaju veći stupanj motivacije, angažmana i samoregulacije, a uključuju planiranje i postavljanje ciljeva vlastitog učenja i regulaciju vlastitih postupaka tijekom učenja (Vrkić i Vlahović Štetić, 2013). Tijekom zadnja dva desetljeća, samoregulirano učenje pokazalo se kao vrlo učinkoviti pokazatelj školskog uspjeha učenika (Pintrich i Groot, 1990; Ablard i Lipschultz, 1998; Kitsantas, 2009; Vrdoljak i Velki, 2012). Prilikom samoreguliranog učenja, učenici su metakognitivno, motivacijski i ponašajno aktivni u vlastitom procesu učenja (Zimmerman i Pons, 1986). Pri tome konstruiraju ciljeve i strategije na temelju informacija iz vanjskog i unutarnjeg svijeta, povezuju nove spoznaje s postojećim znanjima, mentalnim strukturama i vjerovanjima te su odgovorni i imaju kontrolu nad vlastitim učenjem, motivacijom, ponašanjem (Pintrich, 2004). Ako postoji interes za učenje i ako su učenici upoznati s principima samoregulirajućeg učenja, velika je vjerojatnost da će učenje biti uspješnije.

S obzirom da okruženje i osobine učenika (uključujući i misli, osjećaje i ponašanje) jako utječu na školski uspjeh (Babarović i sur., 2009; Vrdoljak i Velki, 2012), ovim istraživanjem se nastojao usporediti školski uspjeh učenika petih razreda na temelju interesa koji učenici imaju za nastavnu temu koja se uči te učeničkih aktivnosti u vlastitom procesu učenja. Konkretno, ovo istraživanje usmjereno je na ispitivanje povezanosti: (i) početne zainteresiranosti učenika za teme vezane uz tematsku cjelinu Tlo, (ii) strategija samoregulirajućeg učenja koje učenici koriste tijekom učenja i (iii) uspjeha na pisanoj provjeri provedenom na kraju obrađene tematske cjeline Tlo.

\section{METODE}

U istraživanju provedenom 2019. godine sudjelovalo je 43 učenika u dva odjeljenja petog razreda III. Osnovne škole Varaždin. Učenici su tijekom prvog polugodišta ispunili anketne upitnike putem online obrasca Google forms na satu Prirode pomoću tablet uređaja (Balažinec, 2019) te ispit znanja u 
pisanom obliku. $U$ ovoj analizi od osnovnih informacija o učeniku korištena je ocjena koju su učenici imali iz Prirode i društva na kraju četvrtog razreda.

Kako bi se dobio uvid u zainteresiranost učenika za istraživanje i učenje sadržaja vezanih uz tematsku cjelinu Tlo, učenici su prije obrade ispunili anketni upitnik za utvrđivanje interesa učenika za sadržaj poučavanja (prilog 1). Teme za ispitivanje zainteresiranosti učenika su odabrane na osnovu učeničkih odgovora dobivenim tehnikom oluje ideja. Potom su učenici trebali izraziti vlastiti stupanj zainteresiranosti za istraživanje i proučavanje dvadeset odabranih tema vezanih uz tlo korištenjem Likertove četverostupanjske skale, pri čemu su stupnjevi zainteresiranosti bili sljedeći: 1 - uopće me ne zanima, 2 - ne zanima me, 3 - zanima me, 4 -vrlo sam zainteresiran.

Obrada tematske cjeline Tlo razrađena je kroz 14 nastavnih sati i 9 nastavnih tema (Građa tla, Vrste tla, Svojstva tla, Životni uvjeti u tlu, Mjerenje temperature tla, Projekt temperatura tla kroz godišnja doba, Izrada lumbrikarija, Prilagodba živih bića životnim uvjetima u tlu, Utjecaj živih bića na životne uvjete $u$ t/u), uključujući poučavanje tijekom terenske nastave i strukturirano promatranje uz pokuse (npr. mjerenje propusnosti tla, određivanje teksture tla, taloženje čestica tla u menzuri, izrada lumbrikarija). Razrada nastavnih tema najvećim dijelom se temeljila na implementaciji GLOBE protokola za tlo (GLOBE Hrvatska, 2010; Program GLOBE - Hrvatska, 2020), koji su prihvatljivi za provedbu kod učenika u dobi od 11 godina.

Prije pisane provjere znanja, upitnikom 2 ispitane su strategije učenja koje učenici primjenjuju tijekom učenja Prirode (prilog 2) na osnovu prethodnog poučavanja na temu Učiti kako učiti, a bez poticaja učitelja Prirode na njihovu izvedbu. $U$ istom je upitniku provjereno i njihovo promišljanje o uspješnosti njihova učenja na nastavi. Upitnik je izrađen i prilagođen prema MSLQ upitniku (Duncan i McKeachie, 2005), a sastojao se od 24 tvrdnje koje su ispitivale: proces učenja, način organizacije informacija, kritičko mišljenje, unutarnju kontrolu, vrijeme i uvjete učenja, trud, suradnju s drugim učenicima tijekom učenja i traženje pomoći. Učenici su trebali izraziti stupanj slaganja s navedenim tvrdnjama koristeći se četverostupanjskom Likertovom skalom pri čemu su stupnjevi slaganja bili sljedeći: 1 uopće se ne slažem, 2 - ne slažem se, 3 - slažem se, 4 - potpuno se slažem. Učenici su također od nekoliko ponuđenih odgovora trebali zaokružiti ono što najčešće koriste prilikom učenja Prirode (knjigu, internet, bilježnicu,...).

Pisana provjera znanja sastojala se od 9 zadataka koji su uključivali 21 česticu. Kognitivne razine znanja određene su u skladu s prilagođenim razinama prema Crooks-u (1988), na način kako je opisano u Radanović i sur. (2010). Prvu kognitivnu razinu znanja (reprodukciju i literarno razumijevanje) provjeravalo je 11 zadataka, 9 zadataka provjeravalo je drugu kognitivnu razinu (primjena $\mathrm{i}$ konceptualno razumijevanje), a jedan je zadatak provjeravao treću kognitivnu razinu (rješavanje problema). Tipovi pitanja u pisanoj provjeri znanja bili su: dva pitanja alternativnog izbora, dva pitanja višestrukog izbora, 3 pitanja povezivanja i sređivanja, dva zadatka dopunjavanja, pet zadataka kratkih odgovora, sedam zadataka proširenog odgovora. Bilo je moguće sakupiti 35 bodova. Podaci uspješnosti na osnovu srednje postotne riješenosti provjere znanja slijede normalnu distribuciju ( $M=71.43 \pm$ 14.31\%). Koeficijent pouzdanosti korištenih opisnica uspješnosti učenja uz provjeravanu tematsku cjelinu Tlo je prihvatljiv $(\alpha=0,760)$.

Učenički odgovori kodirani su pomoću apsolutnih brojčanih vrijednosti (tablica 1), što je omogućilo statističku metrijsku analizu prikupljenih podataka te njihovo kvantificiranje. Svaki odgovor dodatno je procijenjen prema kriterijima točnosti i razini razumijevanja prema Radanović i sur. (2016). Zbog 
potrebe interpretacije odgovora u kontekstu biološkog konceptualnog razumijevanja, kod zadataka otvorenog tipa određena je kognitivna kvaliteta odgovora uz specifično kodiranje biološkog značenja prema Radanović i sur. (2016). Za usporedbu riješenosti zadataka prema kognitivnim razinama koristila se metodologija svrstavanja učenika u 10 klasa uspješnosti prema ukupnom postignutom uspjehu pri rješavanju pisane provjere znanja. Pri tome je izračunat ukupan postotak riješenosti pisane provjere te je svaki učenik, na osnovu postignutog postotnog uspjeha pri rješavanju provjera, svrstan u određenu klasu riješenosti od 1 do 10 u koraku od $10 \%$, čime je omogućeno i utvrđivanje miskoncepcija ili pogrešaka na razini pogrešnih odgovora na zadatke u pisanoj provjeri znanja (prema Radanović i sur., 2017).

Tablica 1 Skale za kodiranje točnosti odgovora i razina razumijevanja prema Radanović i sur. (2016); MA - metrijska analiza; $\mathrm{RR}$ - razina razumijevanja

\begin{tabular}{|l|c|c|c|}
\hline $\begin{array}{c}\text { Riješenost } \\
\text { zadatka }\end{array}$ & MA & Razina razumijevanja & RR \\
\hline točno & 1 & konceptualno razumijevanje & 6 \\
\hline netočno & 0 & djelomično konceptualno razumijevanje & 5 \\
\hline & & primjena & 4 \\
\hline & prepoznavanje & 3 \\
\hline & reprodukcija & 2 \\
\hline & konceptualno nerazumijevanje & 1 \\
\hline & besmisleno & 0 \\
\hline & nema odgovora & 9 \\
\hline
\end{tabular}

Za potrebe ovog istraživanja, iz tematske cjeline poučavanja odabrani su ishodi učenja koji podupiru učenje građe i svojstva tla (tablica 2 ), a pri pripremi nastave i istraživačkih zadataka korišteni su GLOBE protokoli za tlo (The GLOBE program, 2019).

Tablica 2 Odabrani ishodi tematske cjeline Tlo kao osnova analize uspješnosti učenja

\begin{tabular}{|l|l|l|}
\hline \multicolumn{1}{|c|}{ ODGOJNO-OBRAZOVNI ISHOD } & \multicolumn{1}{c|}{ Razrada ishoda } \\
$\begin{array}{l}\text { OŠ PRI A.5.1. Učenik objašnjava } \\
\text { temeljnu građu prirode. }\end{array}$ & $\begin{array}{l}\text { A.5.1.2. Uočava na temelju praktičnih radova } \\
\text { da su tvari građene od sitnih čestica }\end{array}$ & $\begin{array}{l}\text { A.5.1.2.1. Opisuje na temelju praktičnih radova } \\
\text { građu tla uz razlikovanje slojeva u tlu }\end{array}$ \\
\hline $\begin{array}{l}\text { OŠ PRI B.5.1. Učenik objašnjava } \\
\text { svojstva zraka, vode i tla na temelju } \\
\text { istraživanja u neposrednom okolišu. }\end{array}$ & $\begin{array}{l}\text { B.5.1.1. Istražuje sastav i svojstva zraka vode i } \\
\text { tla }\end{array}$ & $\begin{array}{l}\text { B.5.1.1.1. Upotrebom osjetila određuje svojstva } \\
\text { tla i povezuje ih s građom }\end{array}$ \\
\hline $\begin{array}{l}\text { OŠ PRI D.5.1. Učenik tumači uočene } \\
\text { pojave, procese i međuodnose na } \\
\text { temelju opažanja prirode i }\end{array}$ & $\begin{array}{l}\text { D.5.1.3. Bilježi i prikazuje rezultate mjerenja i } \\
\text { opažanja te iz njih izvodi zaključke }\end{array}$ & $\begin{array}{l}\text { D.5.1.3. Prikazuje rezultate mjerenja i opažanja } \\
\text { na osnovu vođenih bilježaka kao osnove za } \\
\text { zaključke. }\end{array}$ \\
\hline $\begin{array}{l}\text { OŠ PRI B.5.2. Učenik objašnjava } \\
\text { međuodnose životnih uvjeta i živih } \\
\text { bića. }\end{array}$ & $\begin{array}{l}\text { B.5.2.1. Objašnjava prilagodbe živih bića u } \\
\text { različitim uvjetima u prirodi na temelju } \\
\text { promatranja, istraživanja u neposrednom } \\
\text { okolišu i praktičnih radova }\end{array}$ & $\begin{array}{l}\text { B.5.2.1.1. Objašnjava prilagodbe živih bića tla u } \\
\text { različitim uvjetima u prirodi na temelju } \\
\text { promatranja, istraživanja u neposrednom } \\
\text { okolišu i praktičnih radova }\end{array}$ \\
\hline
\end{tabular}

Uz 4 odabrana ishoda aktivnosti pridruženo je 8 zadataka vezanih uz građu i svojstva tla (tablica 3, Provjera znanja), 7 učeničkih anketnih odgovora koji podržavaju poučavanje i očekivan način samoregulirajućeg učenja prema izvedbi nastave uz odabranu nastavnu temu (tablica 3, Želim proučavati i istraživati), kao i 7 učeničkih odgovora iz anketnih upitnika, koja su povezana s nastavnim sadržajem i kontekstom poučavanja (tablica 3, Učenje Prirode).

Tablica 3 Povezanost odabranih ishoda učenja, zadataka provjere znanja te upita o interesu učenika i načinu učenja Prirode

\begin{tabular}{|l|l|c|l|l|}
\hline Ishodi aktivnosti & Provjera znanja & $\begin{array}{l}\text { Kognitivna } \\
\text { razina } \\
\text { zadatka }\end{array}$ & $\begin{array}{l}\text { Želim proučavati } \\
\text { i istraživati... }\end{array}$ & Učenje Prirode \\
\hline $\begin{array}{l}\text { A.5.1.2.1. Opisuje na } \\
\text { temelju praktičnih } \\
\text { radova građu tla uz } \\
\text { razlikovanje slojeva u } \\
\text { tlu. }\end{array}$ & $\begin{array}{l}\text { 2.A Na slici je prikazan presjek tla. } \\
\text { Slojevima sa slike pridruži opis tako } \\
\text { da upišeš odgovarajući broj opisa } \\
\text { sloja tla. }\end{array}$ & I. & $\begin{array}{l}\text { A1e ...količinu } \\
\text { zraka i vode u tlu }\end{array}$ & $\begin{array}{l}\text { A2a Kada učim Prirodu radim sheme, } \\
\text { mape, crteže i tablice uz ono što } \\
\text { trebam naučiti. }\end{array}$ \\
\hline
\end{tabular}

Broj 6, prosinac 2020. 


\begin{tabular}{|c|c|c|c|c|}
\hline \multirow[t]{4}{*}{ Ishodi aktivnosti } & Provjera znanja & \multirow[t]{3}{*}{$\begin{array}{l}\text { Kognitivna } \\
\text { razina } \\
\text { zadatka }\end{array}$} & \multirow[t]{3}{*}{$\begin{array}{l}\text { Želim proučavati } \\
\text { i istraživati... }\end{array}$} & Učenje Prirode \\
\hline & \multirow[b]{2}{*}{$\begin{array}{ll}\text { B } & \begin{array}{l}\text { vrsta, korijenje biljaka } \\
\text { 3) puno velikog } \\
\text { kamenja }\end{array}\end{array}$} & & & $\begin{array}{l}\text { A2c Kada učim Prirodu, uvijek } \\
\text { pokušavam otkriti glavnu ideju ili } \\
\text { misao. }\end{array}$ \\
\hline & & & & $\begin{array}{l}\text { A2d Trudim se biti uspješan na } \\
\text { Prirodi čak i ako mi se ne sviđa to što } \\
\text { učimo. }\end{array}$ \\
\hline & $\begin{array}{l}\text { 2.B Osim kamenja, lišća i životinja, } \\
\text { prostor između čestica tla ispunjavaju }\end{array}$ & I. & & $\begin{array}{l}\text { A2e Kada učim Prirodu, koristim se } \\
\text { različitim izvorima informacija. }\end{array}$ \\
\hline $\begin{array}{l}\text { B.5.1.1.1. Upotrebom } \\
\text { osjetila određuje } \\
\text { svojstva tla i povezuje ih } \\
\text { s građom. }\end{array}$ & $\begin{array}{l}\text { 3. Irena i Mirela su u } 300 \text { g uzorka tla } \\
\text { ulile } 200 \mathrm{~mL} \text { vode. Irenin je uzorak } \\
\text { propustio } 80 \mathrm{~mL} \text { vode u } 10 \text { minuta, a } \\
\text { Mirelin uzorak je propustio } 250 \mathrm{~mL} \\
\text { vode u } 10 \text { minuta. } \\
\text { 3.A Čiji je uzorak zemlje koja propušta } \\
\text { manje vode? }\end{array}$ & II. & $\begin{array}{l}\text { A1a ...propusnost } \\
\text { tla }\end{array}$ & $\begin{array}{l}\text { A2a Kada učim Prirodu, radim } \\
\text { sheme, mape, crteže i tablice uz ono } \\
\text { što trebam naučiti. }\end{array}$ \\
\hline \multirow{5}{*}{$\begin{array}{l}\text { D.5.1.3. Bilježi i } \\
\text { prikazuje rezultate } \\
\text { mjerenja i opažanja te iz } \\
\text { njih izvodi zaključke. }\end{array}$} & \multirow{2}{*}{$\begin{array}{l}\text { 3.B Čiji je uzorak zemlje u kojoj ima } \\
\text { više prostora između čestica? } \\
\text { 3.C Čiji je uzorak zemlje koja ima veće } \\
\text { čestice tla? }\end{array}$} & II. & A1b ...rahlost tla & $\begin{array}{l}\text { A2b Kada učim Prirodu, crtam ono } \\
\text { što trebam naučiti. }\end{array}$ \\
\hline & & II. & $\begin{array}{l}\text { A1c ...veličinu } \\
\text { zrnaca u tlu }\end{array}$ & $\begin{array}{l}\text { A2f Znanje iz Prirode puno } \\
\text { primjenjujem u aktivnostima kao što } \\
\text { su projekti, rasprave i praktični } \\
\text { radovi koje radimo na satu. }\end{array}$ \\
\hline & $\begin{array}{l}\text { 3.Da Čija je parcela zemlje pogodnija } \\
\text { za sadnju biljaka? }\end{array}$ & II. & & $\begin{array}{l}\text { A2c Kada učim Prirodu, uvijek } \\
\text { pokušavam otkriti glavnu ideju ili } \\
\text { misao. }\end{array}$ \\
\hline & \multirow[t]{2}{*}{ 3.Db Objasni svoj odgovor. } & II. & & $\begin{array}{l}\text { A2d Trudim se biti uspješan na } \\
\text { Prirodi čak i ako mi se ne sviđa to što } \\
\text { učimo. }\end{array}$ \\
\hline & & & & $\begin{array}{l}\text { A2e Kada učim Prirodu, koristim se } \\
\text { različitim izvorima informacija. }\end{array}$ \\
\hline \multirow{5}{*}{$\begin{array}{l}\text { B.5.2.1.1. Objašnjava } \\
\text { prilagodbe živih bića tla } \\
\text { u različitim uvjetima u } \\
\text { prirodi na temelju } \\
\text { promatranja, } \\
\text { istraživanja u } \\
\text { neposrednom okolišu i } \\
\text { praktičnih radova. }\end{array}$} & \multirow{5}{*}{$\begin{array}{l}\text { 6.B Korijenje biljaka prodire u dublje } \\
\text { slojeve tla. Objasni prednost opisanog } \\
\text { rasta korijenja za biljke, osobito u } \\
\text { zimskom periodu? }\end{array}$} & \multirow[t]{5}{*}{ II. } & $\begin{array}{l}\text { A1d ...biljke koje } \\
\text { rastu u tlu }\end{array}$ & $\begin{array}{l}\text { A2g Pokušavam povezati gradivo } \\
\text { Prirode s drugim predmetima. }\end{array}$ \\
\hline & & & \multirow[t]{4}{*}{$\begin{array}{l}\text { A1g ...utjecaj } \\
\text { reljefa i klime na } \\
\text { tlo }\end{array}$} & $\begin{array}{l}\text { A2f Znanje iz Prirode puno } \\
\text { primjenjujem u aktivnostima kao što } \\
\text { su projekti, rasprave i praktični } \\
\text { radovi koje radimo na satu. }\end{array}$ \\
\hline & & & & $\begin{array}{l}\text { A2c Kada učim Prirodu, uvijek } \\
\text { pokušavam otkriti glavnu ideju ili } \\
\text { misao. }\end{array}$ \\
\hline & & & & $\begin{array}{l}\text { A2d Trudim se biti uspješan na } \\
\text { Prirodi čak i ako mi se ne sviđa to što } \\
\text { učimo. }\end{array}$ \\
\hline & & & & $\begin{array}{l}\text { A2e Kada učim Prirodu, koristim se } \\
\text { različitim izvorima informacija. }\end{array}$ \\
\hline
\end{tabular}

Wilcoxon test proveden je s kodovima odgovora na sva pitanja anketnih upitnika, kao i s kodovima rješenja svih zadataka pisane provjere, kako bi se utvrdile eventualne razlike između učenika s obzirom na njihov interes $\mathrm{i}$ uspješnost (tj. postotak riješenosti provjere znanja) u odnosu na izdvojeni set zadataka koji su analizirani u ovom dijelu istraživanja. Za utvrđivanje povezanosti varijabli (interesa i uspješnosti učenika), korišten je Spearmanov koeficijent korelacije ( $\rho$ ). Za interpretaciju rezultata Spearmanovog koeficijenta korelacije, korištena je skala prema Hopkinsu (2000), koja tumači stupanj koreliranosti (povezanosti) između varijabli u sljedećem rasponu: 0,0-0,1 vrlo mala; 0,11-0,3 mala; $0,31-0,5$ srednja, 0,51-0,7 velika; 0,71-0,9 vrlo velika; 0,9 - 1 potpuna korelacija. $\chi^{2}$ testom je provjeravana ujednačenost odgovora učenika (vezano uz iskaz interesa i slaganja s tvrdnjama o učenju) s obzirom na uspješnost učenika u rješavanju pisane provjere prema klasama riješenosti.

\section{REZULTATI}

Primjenom Wilcoxon testa, utvrđena je statistički značajna razlika za interes učenika $(Z=-3,344 ; p<$ $0,001)$ i riješenost pisane zadaće $(Z=-3,350 ; p<0,001)$. Deset odabranih čestica zadataka povezanih $s$ 
učenjem građe i svojstva tla rješavane su u prosjeku za 9,34 \% ( \pm 8,25 \%) slabije u odnosu na postotak riješenosti cijele pisane provjere. Na osnovu srednje vrijednosti stupnja zainteresiranosti učenika ( $M=$ $3,46 \pm 0,44)$, odabrane teme su zanimljive učenicima, pri čemu su učenici iskazali neznatno veći interes za odabrane teme u odnosu na sve teme. Učenici su se izjasnili da su im odabrani načini učenja Prirode podjednako pomogli pri svladavanju sadržaja iz cijele tematske cjeline, kao i iz tema vezanih uz građu i svojstva tla, što potvrđuje izostanak statistički značajne razlike na osnovu srednjih vrijednosti prema skali slaganja ( $M=3,00 \pm 0,46)$.

Spearmanov koeficijent korelacije pokazao je povezanost između nekih oblika samoregulacijskog učenja i iskazanog interesa učenika za teme vezane uz građu i svojstva tla. Učenici koji svoje znanje često primjenjuju u aktivnostima kao što su projekti, rasprave i praktični radovi (A2c) trude se biti uspješni na Prirodi čak i ako im se ne sviđa ono što uče (A2g). Učenike koje zanimaju fizička svojstva tla i geografske karakteristike (A1a ...propusnost tla; A1b ...rahlost tla; A1f ...dubina, visina i širina tla; A1g ...utjecaj reljefa i klime na tlo) ne zanimaju kemijske i biološke karakteristike tla (tablica 4).

Tablica 4 Povezanost uspješno riješenog pitanja, iskazanog interesa za temu i korištene metode samoreguliranog učenja temeljem Spearmanovog koeficijenta korelacije $(\rho)$ (značajne korelacije označene su uz naznaku razine pouzdanosti: ${ }^{* *} p<$ $0.01, * p<0.05)$

\begin{tabular}{|c|c|c|c|c|c|c|c|c|c|c|c|c|c|c|c|c|c|}
\hline $\begin{array}{l}\text { Spearman } \\
\text { (p) } N=43\end{array}$ & 2.Ab & 2.Ac & 3.B & 3.Db & A1a & A1b & A1c & A1d & A1e & A1f & A1g & $A 2 b$ & A2c & A2d & A2e & A2f & A2g \\
\hline \multirow[t]{19}{*}{ 2.Aa } & $0,80^{* *}$ & & & & & & & & & & & & & & & & \\
\hline & 2.Ab & $0,50^{* *}$ & $0,43^{* *}$ & & & & & & & $-0,31^{*}$ & & & & & & & \\
\hline & & 2.AC & $0,47^{* *}$ & & & & & & & & & & & & & & \\
\hline & & 2.B & & & & & & & & & &,$- 032^{*}$ & & & $-0,36^{*}$ & & \\
\hline & & 3.A & $0,55^{* *}$ & & & & & & & & & & & & & & \\
\hline & & & $3 . \mathrm{C}$ & $0,38^{*}$ & $0,32^{*}$ & & & & & & & & & & & & \\
\hline & & & & 3.Db & $0,40^{* *}$ & & & & & & & & & & & & \\
\hline & & & & & A1a & $0,62^{* *}$ & $0,34^{*}$ & & & $0,48^{* *}$ & $0,47^{* *}$ & & & $0,42^{* *}$ & & $0,47^{* *}$ & \\
\hline & & & & & & A1b & $0,37^{*}$ & $0,37^{*}$ & $0,43^{* *}$ & $0,36^{*}$ & $0,47^{* *}$ & & & & & $0,38^{*}$ & \\
\hline & & & & & & & A1c & $0,54^{* *}$ & $0,45^{* *}$ & & $0,39^{* *}$ & & & & $0,35^{*}$ & & \\
\hline & & & & & & & & A1d & $0,51^{* *}$ & & & & & & & & \\
\hline & & & & & & & & & A1e & $0,62^{* *}$ & $0,34^{*}$ & & & & $0,48^{* *}$ & & \\
\hline & & & & & & & & & & A1f & & $0,38^{*}$ & & $0,36^{*}$ & $0,35^{*}$ & & \\
\hline & & & & & & & & & & & A1g & & & & & $0,40^{* *}$ & \\
\hline & & & & & & & & & & & A2a & & $0,39^{*}$ & $0,32^{*}$ & & & \\
\hline & & & & & & & & & & & & $\mathbf{A} 2 \mathrm{~b}$ & $0,37^{*}$ & $0,38^{*}$ & $0,36^{*}$ & $0,56^{* *}$ & \\
\hline & & & & & & & & & & & & & A2c & $0,50^{* *}$ & & & $0,42^{* *}$ \\
\hline & & & & & & & & & & & & & & A2d & & $0,34^{*}$ & $0,39^{*}$ \\
\hline & & & & & & & & & & & & & & & A2e & & $0,34^{*}$ \\
\hline
\end{tabular}

Također je za tu grupu interesa uočena i srednja povezanost s iskazom A2f „Kad učim Prirodu uvijek pokušavam otkriti glavnu ideju ili misao.“. Učenici iskazuju visoku povezanost interesa između A1c ...veličine zrnaca u tlu i A1d ...biljka koje rastu u tlu (tablica 2). Učenici koje zanimaju mjerne karakteristike (A1e ...količina zraka i vode u tlu; A1f ...dubina, visina i širina tla) crtaju ono što treba naučiti iz Prirode (A2e), odnosno pri učenju rade sheme, mape, tablice i crteže uz ono što uče (tablica 2).

U analizi samoregulirajućeg učenja može se uočiti značajna povezanost (tablica 4) iskaza A2c „Znanje iz Prirode puno primjenjujem u aktivnostima kao što su projekti, rasprave i praktični radovi koje radimo na satu. “ i A2d „Kada učim Prirodu radim sheme, mape, crteže i tablice uz ono što trebam naučiti. Korelacije iz tablice 4 ukazuju da se učenici, koji svjesno primjenjuju znanje tijekom nastave (A2c), rade sheme (A2d) i crtaju (A2e) dok uče, trude biti uspješni čak i ako im se ne sviđa to što uče (A2g). Također je značajna korelacija (tablica 4) uočena između iskaza A2b „Pokušavam povezati gradivo Prirode $s$ drugim predmetima.“ i A2f „Kad učim Prirodu uvijek pokušavam otkriti glavnu ideju ili misao.“. 
$\chi^{2}$ test nije ukazao na statistički značajne razlike u iskazanom interesu učenika različitih klasa riješenosti pisane provjere. Utvrđeno je da nema značajne razlike između zainteresiranosti za tematsku cjelinu Tlo i riješenosti pisane provjere prema klasama riješenosti, odnosno učenici koji su slabije riješili pisanu provjeru znanja kao i učenici koji su je riješili vrlo uspješno, na početku učenja iskazali su jednaku zainteresiranost za učenje o tlu.

Nisu dokazane značajne razlike između učenika različitih klasa riješenosti pisane provjere s obzirom na njihovo slaganje s ponuđenim tvrdnjama vezanim uz učenje - jedino su uz tvrdnju A2f: „Znanje iz Prirode puno primjenjujem u aktivnostima kao što su projekti, rasprave i praktični radovi koje radimo na satu. "opažene značajne razlike između različitih klasa riješenosti $\left(\chi^{2}=21,662 ; p=0,017\right)$. Na slici 1 može se uočiti da se 4,9 \% učenika koji su ostvarili 90 \% riješenosti provjere na slažu s ovom tvrdnjom, a potpuno slaganje je izrazilo $80 \%$ učenika koji su riješili provjeru do $80 \%$ točnosti.
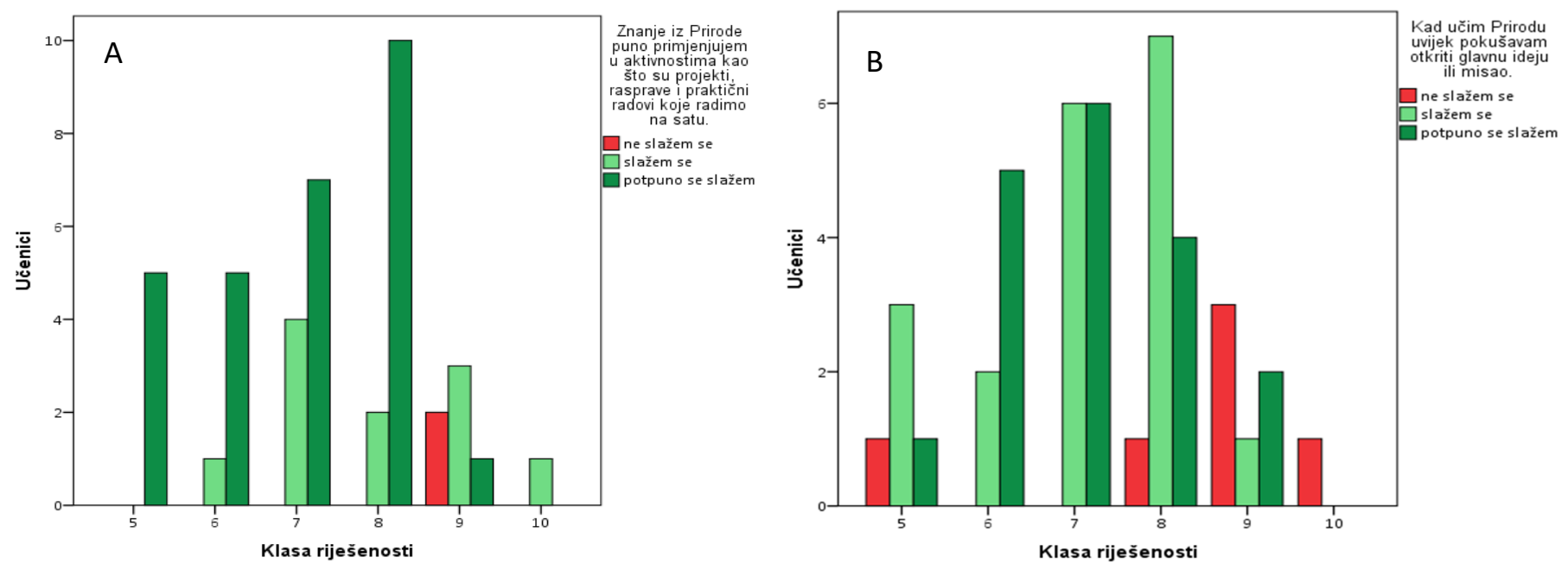

Slika 1 Slaganje učenika s tvrdnjom prema klasama riješenosti pisane provjere: A. „Znanje iz Prirode puno primjenjujem u aktivnostima kao što su projekti, rasprave i praktični radovi koje radimo na satu.“ B. „Kad učim Prirodu uvijek pokušavam otkriti glavnu ideju ili misao."

Slaganje učenika različitih klasa riješenosti pisane provjere s tvrdnjom A2c „Kad učim Prirodu uvijek pokušavam otkriti glavnu ideju ili misao." također ukazuje na statistički značajne razlike između učenika različite uspješnosti $\left(\chi^{2}=19,676 ; p=0,032\right)$. 11,6 \% učenika, koji su u provjeri riješili više od 80 \% zadataka (uključujući i najuspješnije učenike pri rješavanju provjere), ne razmišlja dok uči (slika 1).

Učenici su pri rješavanju zadatka 2.A trebali koristiti reproduktivno znanje uz prepoznavanje slojeva tla, prema sličnoj slici koja je bila korištena pri poučavanju. Zadatak se pokazao lagan za učenike $(p=$ $0,77)$. Ako se zasebno promatraju čestice tog zadatka, riješenost laganih čestica a $(p=0,84)$ i b $(p=$ $0,77)$ je vrlo povezana $(\rho=0,801, p<0,01)$. Pri rješavanju čestice b zadatka $2 . A$, gdje su učenici trebali povezati na slici prikazan SLOJ B $s$ „manje životinjskih vrsta i korijenje biljaka“ uočena je statistički značajna razlika između klasa riješenosti $\left(\chi^{2}=20,454 ; p=0,001\right)$, zbog toga jer se netočni odgovori (23,3 \%) javljaju kod učenika slabijih od klase $50 \%$ sve do učenika koji pripadaju klasi $80 \%$ riješenosti (slika 2). Spearmanovim koeficijentom korelacije utvrđeno je da su učenici uspješno rješavali i 2.Aa i 2.Ab čestice zadatka (tablica 4). Učenicima prelaganu česticu c zadatka 2.A nije točno riješilo samo 7 \% učenika najslabije klase riješenosti ( $50 \%$ ), jer nisu povezali na slici prikazan SLOJ C s puno velikog kamenja, zbog čega se javlja statistički značajna razlika pri rješavanju ovog zadatka $\left(\chi^{2}=24,510 ; p<\right.$ $0,001)$. 


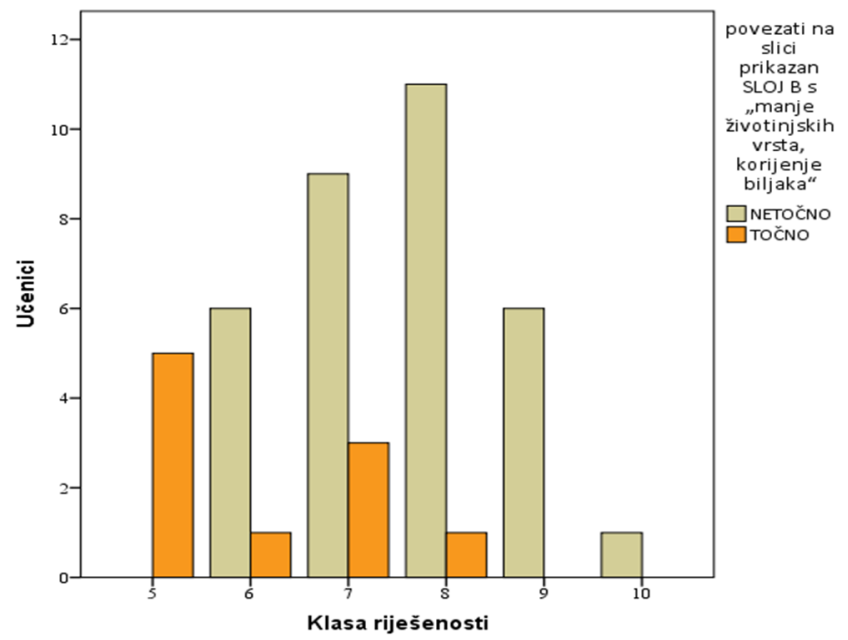

Slika 2 Riješenost čestice zadatka 2Ab u kojoj su učenici trebali povezati na slici prikazan SLOJ B s „manje životinjskih vrsta, korijenje biljaka"

Zanimljivo je da je riješenost čestica zadatka 2.Ab, 2.Ac te čestice zadatka 3.B, koje su vezane uz osnovne principe karakteristične za slojeve tla, međusobno umjereno korelirana (tablica 4), a negativno je korelirana s iskazom interesa (A1f) za učenje uz „....dubinu, visinu i širinu tla“ (tablica 4), odnosno učenici koji su točno odgovorili većim dijelom nisu iskazali interes.

Zadatak 2.B, koji provjerava činjenicu da prostor između čestica tla ispunjavaju voda i zrak netočno je riješilo 32,6 \% učenika. Utvrđena je negativna korelacija riješenosti ovog zadatka sa svjesnošću učenika da to znanje treba primijeniti u drugim aktivnostima učenja. Učenici koji su ostvarili znanje na razini reprodukcije uz zadatak 2.B ne prepoznaju primjenu svog znanja u aktivnostima poput projekata, rasprava i praktičnih radova $\left(\rho_{A 2 c}=-0,316 ; p<0.05\right)$, a također ne traže glavnu ideju ili misao kada uče Prirodu $\left(\rho_{A 2 f}=-0,360 ; p<0.05\right)$. Negativni smjer korelacije ukazuje na to da učenici koji su dobro riješili taj zadataka misle suprotno od pozitivnog usmjerenja upita, a kao što se već ranije utvrdilo, to je $5 \%$ učenika koji pripadaju klasi 9 riješenosti (90 \%). Riješenost zadatka 2.B srednje je negativno povezana $s$ iskazom učenika $A 2 b$ "Pokušavam povezati gradivo Prirode s drugim predmetima." kao i s iskazom A2e "Kada učim Prirodu crtam ono što trebam naučiti“ (tablica 4, slika 3).
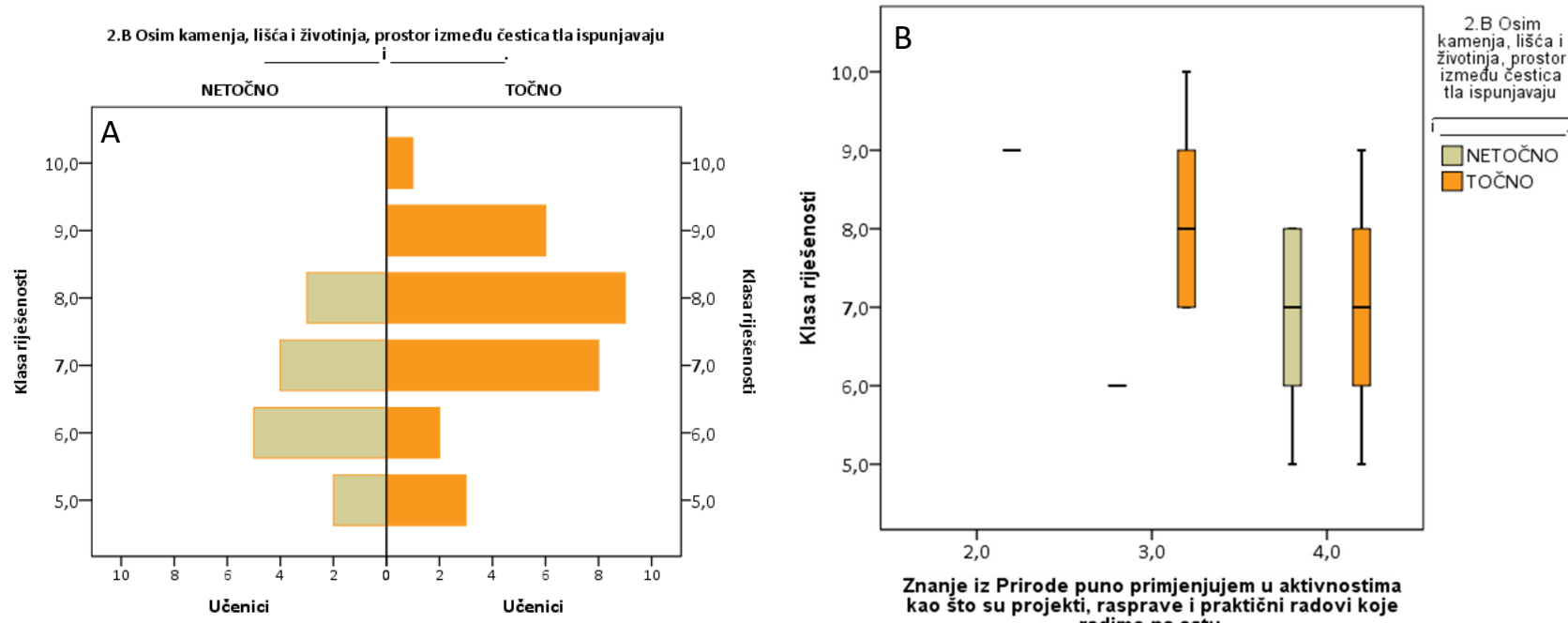

Slika 3 Riješenost zadatka 2.B (A) i iskaz učenika A2b (B) prema klasama riješenosti

U 3. zadatku učenici su trebali svoje znanje uz pokus koji su radili na nastavi primijeniti uz zadane vrijednosti i pokazati svoje razumijevanje propusnosti vode u tlu. Zadatak je u cijelosti riješilo samo 5 
\% učenika te za njih možemo tvrditi da su ostvarili konceptualno razumijevanje. Usprkos toga, učenici su bili puno uspješniji pri rješavanju pojedinih čestica tog zadatka. Čestica A 3. zadatka učenicima je bila čak i prelagana (91 \% riješenosti), a česticu B 3. zadatka koja se pokazala učenicima lagana uspješno je riješilo 74 \% učenika. Usprkos toga, broj pogrešnih odgovora učenika $(26 \%$ ) raste s padom klase riješenosti (slika 4) za česticu B „Čiji je uzorak zemlje u kojoj ima više prostora između čestica tla?“, što je rezultiralo statistički značajnim razlikama riješenosti $\left(\chi^{2}=11,846 ; p=0,037\right)$.

Česticu C 3. zadatka „Čiji je uzorak zemlje koja ima veće čestice tla?“ riješilo je samo 35 \% učenika, a između njih nisu bili najuspješniji učenici na provjeri, što ponovo potvrđuje da su skloni reproduktivnom učenju. Najviše točnih odgovora (14 \%) bilo je u klasama učenika koji su provjeru rješavali s do 70 \% i 80 \% riješenosti (slika 4).
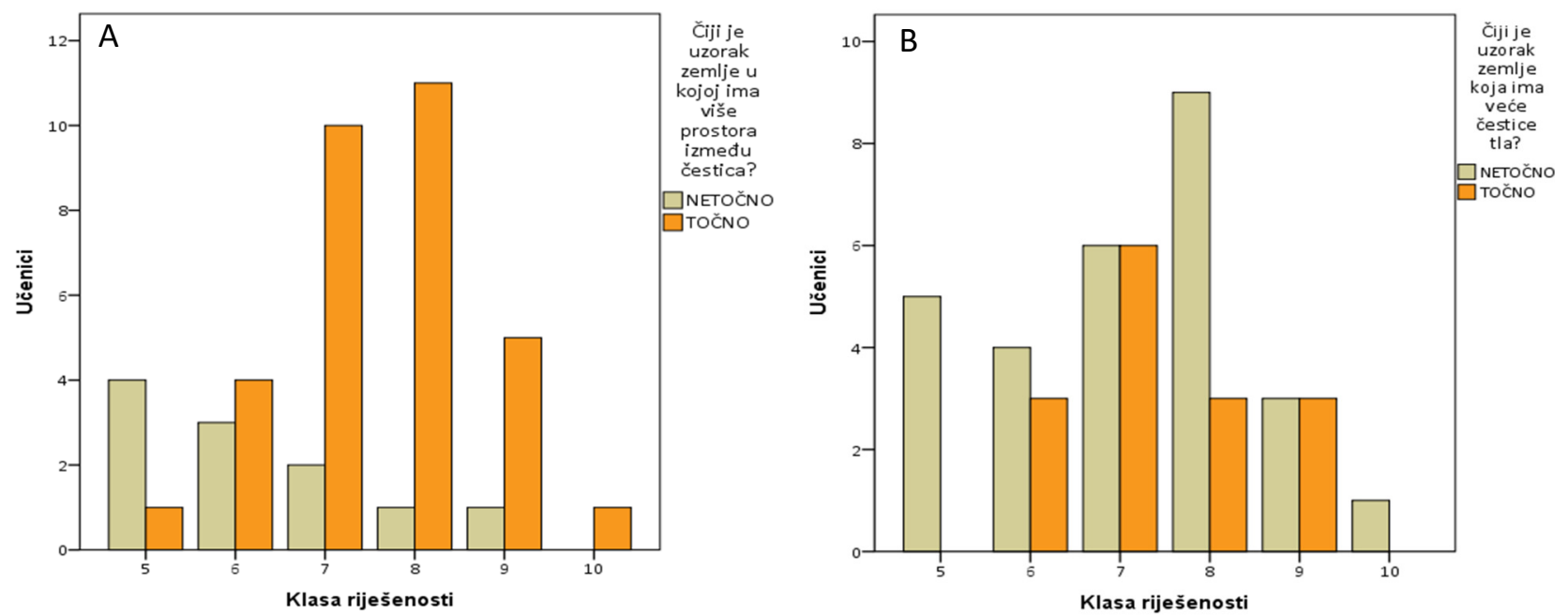

Slika 4 Riješenost čestica 3. zadatka: A. 3B „Čiji je uzorak zemlje u kojoj ima više prostora između čestica?“, B. 3D „Čiji je uzorak zemlje koja ima veće čestice tla?"

lako je čestica 3.D zadatka „Čija je parcela zemlje pogodnija za sadnju biljaka? Objasni svoj odgovor.", u kojoj se uz odgovor na dio a traži i objašnjenje u dijelu b („Irenina, jer zadržava više vode koju biljke mogu iskoristiti."), bila prihvatljive težine za učenike, može se uočiti da je samo $28 \%$ učenika uz točan odgovor ponudilo točno objašnjenje te je to ipak bio učenicima težak zadatak provjere konceptualnog razumijevanja. Pri tome, odgovor se nije usudilo ponuditi čak 30,2 \%, dok je 41,9 \% učenika pokazalo konceptualno nerazumijevanje, ponudivši odgovore bez objašnjenja poput: „U Mirelinom uzorku se zadržava više vode. "; „Irenina zemlja ima manje vode. "; „Mirelina zemlja ima više čestica.". Učenici koji su iskazali visoku zainteresiranost za učenje o propusnosti tla (A1a) ostvarili su visoku primjenu i konceptualno razumijevanje nudeći točno objašnjenje (3.Db) uz zadatak 3.D koji provjerava upravo to znanje (tablica 4).

Rješavanje čestica zadataka 3.A i 3.B, koje provjeravaju primjenu znanja uz povezivanje veličina čestica tla i propusnosti tla visoko je povezano (tablica 4). Riješenost čestice zadatka 3.C „Čiji je uzorak zemlje koja ima veće čestice tla?“ srednje je povezano (tablica 4) s objašnjenjem čestice zadatka 3.Db „Čija je parcela zemlje pogodnija za sadnju biljaka? Objasni svoj odgovor." Riješenost obje ove čestice zadatka srednje je povezana s iskazom interesa A1a uz „....propusnost tla“ (tablica 4) te su učenici kojima je to područje zanimljivo bili uspješniji u primjeni znanja i ostvarivanju konceptualnog razumijevanja vezanog uz zadržavanje vode koju biljke mogu iskoristiti. 
Učenici koji pokazali reprodukciju znanja uz čestice zadatka 2.A točno su riješili i česticu zadatka 3.B (tablica 4) te su pokazali primjenu znanja i konceptualno razumijevanje uz cijeli 3 . zadatak $\left(\rho=0,399^{* *} p\right.$ < 0.01). Uvidom u interpretaciju odgovora 3.D čestice zadatka može se uočiti da je konceptualno razumijevanje pokazalo samo $27,9 \%$ učenika, a čak $30,2 \%$ učenika nije se usudilo ponuditi odgovor. Riješenost zadatka pokazuje statistički značajnu razliku između klasa riješenosti $\left(\chi^{2}=14,751 ; p=0,011\right)$, pri čemu je pogrešno objašnjenje ponudilo $44,2 \%$ učenika koji su riješili provjeru sa $50 \%$ do $70 \%$ riješenosti. Zanimljivo je da učenici koji su ostvarili samo 50 \% riješenosti ipak mogu riješiti ovu česticu zadatka koja traži konceptualno razumijevanje (slika 5).

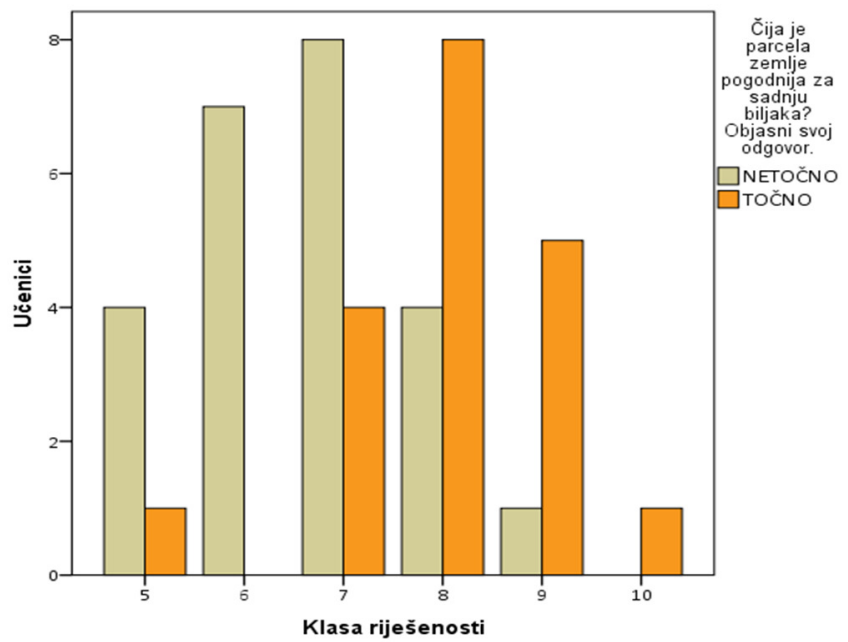

Slika 5 Objašnjenje odgovora uz česticu zadatka 3.D „Čija je parcela zemlje pogodnija za sadnju biljaka?"

Usporedba razine razumijevanja propusnosti vode u tlu, koja se provjeravala u 3. zadatku, prema klasi riješenosti i s obzirom na ocjenu koju su učenici imali iz Prirode i društva na kraju četvrtog razreda ukazuje na statistički značajne razlike samo kod učenika koji su imali ocjenu odličan $\left(\chi^{2}=38,346 ; p=\right.$ 0,008 ). Od tih učenika, konceptualno nerazumijevanje pokazalo je $5,7 \%$ učenika koji su provjeru riješili u klasi $60 \%$ riješenosti (slika 6).

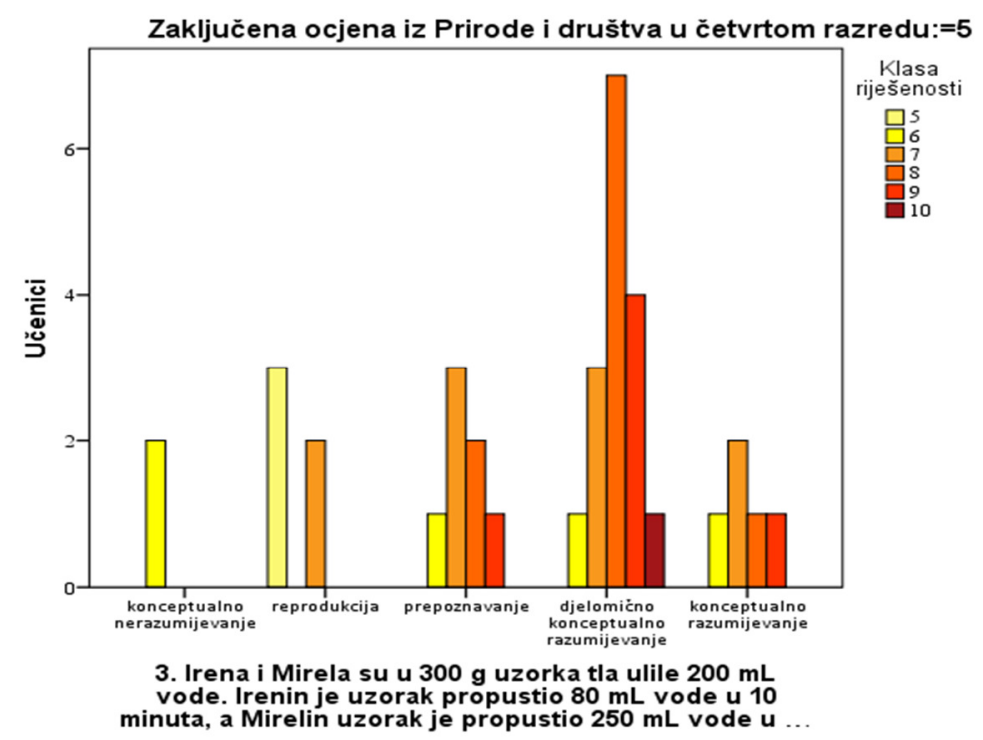

Slika 6 Razina razumijevanja 3. zadatka uz propusnost vode u tlu prema klasi riješenosti kod učenika koji su imali odličan na kraju 4. razreda iz Prirode i društva

Tim je učenicima najveći problem predstavljalo povezivanje i primjena znanja u stvarnom životu pa su odgovarali: Mirelina zemlja je pogodnija za sadnju jer propušta više vode. To upućuje na to da učenici 
znaju odgovoriti na pitanja reproduktivnog tipa ali imaju problema s primjenom znanja i konceptualnim razumijevanjem. Neki od tih učenika su potpuno pogrešno zaključili da je Irenina zemlja bolja za sadnju jer ima manje vode i Mirelina zemlja je bolja za sadnju jer zadržava više vode. 5,7 \% bivših odličnih učenika koji su ostvarili od $70 \%$ do 79 \% riješenosti točno riješili zadatak gdje se tražilo reproduktivno znanje (Čija zemlja propušta više vode?), ali su pogrešno odgovarali na pitanja koja su tražila višu razinu razumijevanja (Čiji je uzorak zemlje u kojoj ima više prostora između čestica?). Isto tako 2,9 \% učenika unutar klase 90 \% riješenosti pokazalo je samo prepoznavanje u svojim odgovorima (slika 6). Oni prepoznaju da uzorak zemlje koja ima više prostora među česticama propušta više vode, ali ne povezuju veličinu prostora s veličinom čestica.

Zadatak 6.B „Korijenje biljaka prodire u dublje slojeve tla. Objasni prednost opisanog rasta korijenja za biljke, osobito u zimskom periodu?" je učenicima bio težak zadatak $(p=0,14)$ uz statistički značajnu razliku između klasa riješenosti $\left(\chi^{2}=16,625 ; p=0,005\right)$. Veliki broj učenika $(39,5 \%)$ unutar svih klasa riješenosti, osim dvije najuspješnije (klasa 9 i 10), nije odgovorio na ovo pitanje (slika 7).
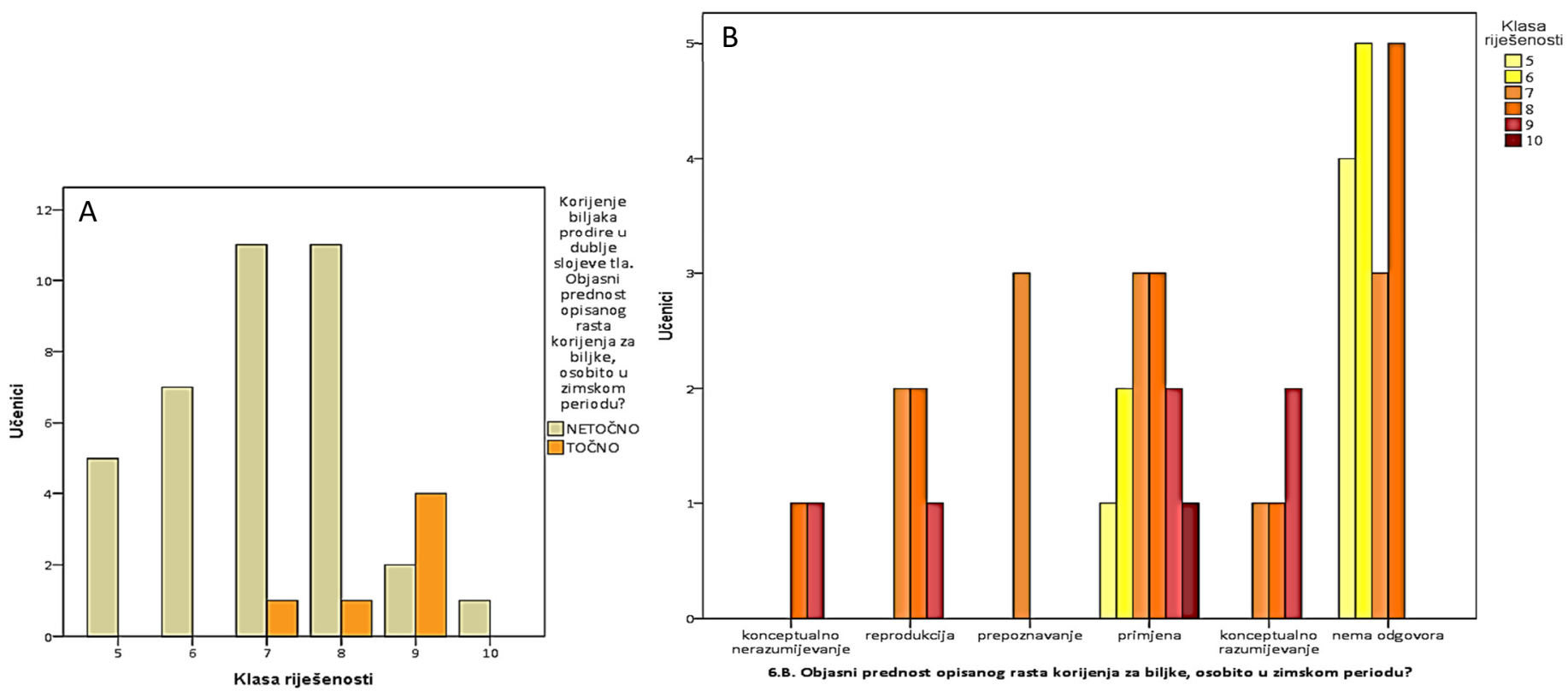

Slika 7 Riješenost (A) i razina razumijevanja (B) zadatka 6.B „Korijenje biljaka prodire u dublje slojeve tla. Objasni prednost opisanog rasta korijenja za biljke, osobito u zimskom periodu?"

U ovom zadatku, najuspješniji učenici ne daju točno objašnjenje (slika 7), već se njihov odgovor (npr. „dolje je toplije") temelji na ponavljanju primjene znanja sa nastave. Konceptualno nerazumijevanje pokazuje manji dio učenika $(4,7 \%)$, ali oni pripadaju 8 i 9 klasi riješenosti provjere. Točan odgovor uz konceptualno razumijevanje (,U dubljim dijelovima tla ima dostupne vode za biljku i tijekom zime.") nudi samo $14 \%$ učenika koji pripadaju klasama riješenosti od $70 \%$ do $90 \%$ (slika 7).

\section{RASPRAVA}

Istraživanje je pokazalo kako učenici na početku učenja pokazuju visoku zainteresiranost za cjelinu Tlo, što je u skladu i sa rezultatima prethodno provedenog istraživanja (Balažinec, 2019). Utvrđeno je da nema značajne razlike između zainteresiranosti za tematsku cjelinu Tlo i riješenosti pisane provjere prema klasama riješenosti, ali je uočeno da su učenici, koji su pokazali interes za učenje o određenoj temi (npr. propusnosti tla), bolje rješavali pitanja koja su tražila znanje o tome, što je u skladu $\mathrm{s}$ 
istraživanjima Pintrich i Groot (1990), koji su zaključili da zainteresiranost za temu utječe na kognitivnu uključenost dvanaestogodišnjaka.

Visoka povezanost interesa između „...veličine zrnaca u tlu“ i „...biljka koje rastu u tlu“, ukazuje na razmišljanje o povezanosti ta dva parametra. Na takve rezultate je vjerojatno imalo utjecaj i prethodno učenje, jer su učenici u 4. razredu iz predmeta Priroda i društvo sadili svoje vlastite gredice s povrćem i osobno (rukama) proučavali tlo na kojem će saditi biljke pa su imali određeno predznanje na tom području. Učenici koje zanimaju mjerne karakteristike crtaju ono što treba naučiti, odnosno pri učenju rade sheme, mape, tablice i crteže uz ono što uče, što ukazuje na njihovu izraženu vizualnu orijentaciju pri učenju s razumijevanjem (Latin i sur, 2016; Novak i Cañas, 2007).

Učenici koji uočavaju primjenjivost znanja u aktivnostima poput projekata, skloni su sistematizirati svoje znanje i trude se biti uspješni iz Prirode, čak i kad im se ne sviđa ono što uče, što ukazuje da učenici koji žele sistematizirati svoje znanje uočavaju njihovu primjenjivost u različitim aktivnostima na nastavi. Do sličnog zaključka došli su i Pintrich i Groot (1990) u svom istraživanju, u kojem tvrde kako učenici koji izvještavaju o samoreguliranom učenju, izvještavaju i o većim razinama intrinzične motivacije za učenje. Takav zaključak podupire i istraživanje Archer i sur. (1999), koji su utvrdili da uspješno učenje i obavljanje nekog zadatka uključuje složeno međudjelovanje motivacijskih, kognitivnih, samoregulacijskih, samoevaluativnih, okolinskih i afektivnih činitelja. Primjer takvog složenog međudjelovanja je aktivnost izrade lumbrikarija koja je slijedila nakon provjere. Prilikom izrade lumbrikarija, učenici su, kako bi uspješno riješili zadatak, morali primijeniti svoje znanje vezano uz građu i svojstva tla (kako bi odlučili od čega će izraditi lumbrikarij) te na kraju pretpostaviti kakve promjene će se dogoditi nakon određenog vremena u lumbrikariju. Nakon što su aktivnost priveli kraju, osvrnuli su se na svoj rad i pretpostavke. Da bi učenici uspješno savladali ovaj zadatak, morali su biti motivirani za izradu lumbrikarija, promisliti i dogovoriti s kolegama kako će ga izraditi i pri tome upotrijebiti već stečena znanja o svojstvima i građi tla te se na kraju osvrnuti na svoju izvedbu tijekom samovrednovanja. Značajna korelacija između iskaza o nastojanju povezivanja učenja na Prirodi s učenjem na drugim predmetima $\mathrm{i}$ iskaza o usmjerenosti prema otkrivanju glavne ideje ili misli kod učenja potvrđuje da učenici koji žele razumjeti ono što uče, intuitivno integriraju svoje znanje, jer istovremeno žele povezati znanje jednog područja sa znanjima drugih područja učenja, ali i s onim znanjima koja nisu jasno istaknuta kao osnova učenja tijekom poučavanja.

Učenici koji su dobro riješili pitanja koja traže reproduktivno znanje nisu skloni povezivanju gradiva, primjeni u drugim aktivnostima na satu niti traženju glave ideje kada uče te nisu skloni povezivanju i crtanju pri učenju. Većinom su to učenici slabijih sposobnosti koji ističu: „Kad učim za test, pokušavam zapamtiti novo gradivo onako kako je napisano u knjizi.“ i „Jako sam zadovoljan kad nemam puno za učiti." Ovakvi rezultati u skladu su sa istraživanjem Rijavec i sur. (1999), u kojem se došlo do zaključka kako su lošiji učenici skloniji učiti novo gradivo oslanjajući se uglavnom na njegovo memoriranje, usmjeravaju se samo na ono što misle da će učitelj pitati i ne razmišljaju puno, nego ponavljaju dok im se ne učini da su naučili. U skladu sa zaključkom Vrkić i Vlahović Štetić (2013), prema kojima se ponavljanje odnosi na površinsko procesiranje informacija (tzv. učenje napamet), pri čemu se informacije mehanički ponavljaju s ciljem reprodukcije u originalnom obliku, učenici koji svoje znanje temelje na ponavljanju kao nižem obliku kognitivnog učenja u svojim odgovorima koja traže objašnjenje koriste reproducirane definicije s nastave poput ",kako nastaje tlo“, „,što se sve nalazi u tlu“. U svrhu dubinskog procesiranja informacija tijekom izvedbe pokusa, u kojem su učenici povezivali veličinu čestica s njihovom brzinom taloženja, potaknute su strategije organizacije kognitivnog učenja. 
lako se u aktivnosti pokušalo potaknuti stvaranje smislenih i povezanih cjelina na način da se prepoznaju najvažniji elementi i njihovi međusobni odnosi, što je u skladu sa zaključkom Vrkić i Vlahović Štetić (2013), poveznice nisu svim učenicima bile dovoljno uočljive. Također tijekom poučavanja poticana je primjene strategije elaboracije u učenju, a prema zaključku Vrkić i Vlahović Štetić (2013) da se elaboracija ponajprije odnosi na traženje veza između nastavnog sadržaja koji se uči i onoga što znamo otprije te uvođenje novih pravila organizacije. $U$ tu svrhu učenici su trebali osmisliti pokus kojim će dokazati koje tlo propušta najviše vode i pri tome odgovoriti na pitanja „Koliko vode će ulijevati? Kako će ulijevati vodu? Što će mjeriti? Kako će mjeriti?" te osmisliti pretpostavku na temelju svojih dosadašnjih saznanja o svojstvima tla. Na osnovu pripreme grafičkog prikaza prema sakupljenim tabličnim podacima učenici su vođeni do zaključka da je temperatura tla povezana s temperaturom zraka te da je temperatura tla na $5 \mathrm{~cm}$ viša od temperature tla na $10 \mathrm{~cm}$ u proljetnom periodu dok je u zimskom periodu obrnuto što je bio poticaj za daljnju organizaciju znanja na osnovu analize primjera razlika s obzirom na klimu i temperaturne uvjete u različitim mjestima u RH. Takva elaboracija ipak se sama po sebi nije pokazala uvijek dovoljno učinkovita, odnosno bila je dobro prihvaćena samo kod manjeg broja učenika, zbog čega je neophodno u poučavanju dobro vizualizirati svaki korak u sistematizaciji i organizaciji znanja pri učenju. Dobri su pokazatelji vizualne sistematizacije uočeni kod korištenja konceptualnih mapa koje omogućuju izgradnju koncepta (Golubić i sur, 2019) te bi je bilo poželjno postupno uvoditi kao alat za postizanje konceptualnog razumijevanja tijekom poučavanja već i kod učenika u dobi 11 godina, prvo uz primjenu ekspertnih mapa objašnjenih u priči uz pomoć učitelja, a kasnije u samostalnoj izradi učenika.

Učenici najslabije klase riješenosti nisu prepoznali na slici prikazan sloj s puno velikog kamenja. Takav rezultat upućuje da je učenicima slabijih mogućnosti potrebno ukazati veću pažnju pri izvedbi praktičnog rada te tražiti na terenu različitim načinima provjere prepoznavanje slojeva tla, ali i njihov opis i objašnjenje zašto su tako građeni te što takva građa znači za živi svijet. Učenici koji su točno riješili zadatke vezane uz osnovne karakteristike slojeva tla većim dijelom nisu iskazali interes za učenje uz „...dubinu, visinu i širinu tla“. Djelomično se objašnjenje može pronaći u činjenici da su te čestice provjere tražile reproduktivna znanja vezana uz sastav tla pojedinog sloja, a iskaz interesa je upućivao na konkretna mjerenja. Broj pogrešnih odgovora učenika raste s padom klase riješenosti kada se učenike traži da primjene znanje na konkretnom primjeru vezanom uz prostor između čestica tla te ukazuje na probleme primjene znanja kod učenika slabijih sposobnosti i potrebu za više vježbe rješavanja takvih zadataka na nastavi, što su utvrdili i Zidar i sur. (2018).

Učenici koji su tijekom poučavanja sudjelovali u aktivnostima učenja s praktičnim radom uspješno rješavaju zadatke koji provjeravaju primjenu znanja povezivanjem dviju varijabli (npr. uz povezivanje veličina čestica tla i propusnosti tla), što znači da veliki broj učenika dobro povezuje koncepte koji su se mogli dublje upoznati i bolje organizirati tijekom primjene praktičnog rada. Takav zaključak je u skladu s analizom utjecaja praktičnog rada na motivaciju učenika (Abrahams, 2009). Kada se od učenika uz odgovor traži i objašnjenje za provjeru konceptualnog razumijevanja i kod zadataka prosječne težine, može se uočiti da točno objašnjenje nudi oko polovine učenika koji su dali točan odgovor. Takav rezultat potvrđuje zapažanje da kod zadataka gdje je potrebno dati objašnjenje uz odgovor učenici zasebno točno rješavaju pojedinu česticu u pravilu dvostruko bolje od točno riješenog cijelog zadatka, a tim se zadacima upravo može provjeriti konceptualno razumijevanje i potrebno ih je zajedno bodovati. 
Samo jedna trećina učenika koji su imali ocjenu odličan iz Prirode i društva na kraju četvrtog razreda pokazuje konceptualno razumijevanje kod provjere viših razina znanja o potrebnim svojstvima zemlje s obzirom na sadnju biljaka. Tim je učenicima najveći problem predstavljalo povezivanje i primjena znanja u stvarnom životu pa su odgovarali: „Mirelina zemlja je pogodnija za sadnju jer propušta više vode." Takav odgovor upućuje da učenici znaju odgovoriti na pitanja reproduktivnog tipa ali imaju problema s primjenom znanja i konceptualnim razumijevanjem kada treba povezati dva odgovora koja pojedinačno mogu točno formulirati. Slične probleme s povezivanjem rezultata promatranja ili mjerenja pri pripremi njihovog objašnjavanja uočile su i Karakaš i Begić (2018). Zadatak u kom su učenici trebali opisati povezanost dubinskog rasta korijenja za biljke sa životnim uvjetima i vodnim režimom u zimskom periodu je učenicima bio težak te ga rješavaju samo dvije najuspješnije klasa $s$ obzirom na riješenost, a ostali učenici većim dijelom niti ne pokušavaju dati odgovor na ovo pitanje. Takav rezultat se podudara sa zaključkom Begić i sur. (2017) da teške zadatke uspješno rješavaju najuspješniji učenici, ali i dio učenika u svim klasama uspješnosti osim najslabije Najuspješniji učenici ne daju točno objašnjenje, već se njihov odgovor (npr. „dolje je toplije") temelji na primjeni iskustva koje su stekli na satu mjereći temperaturu tla na 5 i $10 \mathrm{~cm}$ u zimskom periodu, što ukazuje na reproduktivni karakter njihova učenja, bez uočavanja neophodne povezanosti i povezivanja varijabli pri formuliranju objašnjenja. Točan odgovor uz konceptualno razumijevanje (,,U dubljim dijelovima tla ima dostupne vode za biljku i tijekom zime. ") nudi manji broj uspješnije trećine učenika prema klasama riješenosti. Problem lošeg povezivanja znanja pri pripremi objašnjenja odgovora može se uočiti i kod starijih učenika (Golubić i sur, 2017). Učenici često ne osvještavaju svoje učenje i kod pitanja koja traže objašnjenje odgovora, sriču jednostavne odgovore koji često nisu tražena objašnjenja, a što se uočava i kod srednjoškolaca pri rješavanju zadataka na državnoj maturi iz biologije (Radanović i sur, 2017).

Ono što zabrinjava je činjenica da su i uspješni učenici orijentirani na reproduktivno savladavanje gradiva i ne rješavaju pitanja koja traže konceptualno razumijevanje i primjenu viših kognitivnih strategija učenja. Razloge tome možemo pronaći u uvriježenom načinu učenja učenika koji nisu tijekom poučavanja potaknuti u savladavanju vještina učenja, posebno onih koje će osvijestiti njihovo znanja, što potvrđuje zaključak Vrkić i Vlahović Štetić (2013) da učenici u značajnoj mjeri pri rješavanju pisanih provjera znanja, zbog uvriježenog načina učenja, koriste kognitivne strategije učenja. Dio uspješnih učenika ne prepoznaje aktivnosti u kojima se traži povezivanje i upotreba već ranije stečenog znanja iz Prirode. U razgovoru s učenicima na satu Prirode, došlo se do zaključka da učenici smatraju da se u takvim aktivnostima od njih ne traži primjena ranije stečenog znanja iz Prirode i da ne prepoznaju da su to aktivnosti u kojima bi mogli povezati ranije obrađena znanja. Schunk i Zimmerman (1998) naglašavaju kako su učenička uvjerenja među glavnim razlozima zbog kojih učenici ne koriste procese samoregulacije pri učenju. Ovakva učenička objašnjenja upućuju da su učenici još uvijek skloni nastavne sadržaje „spremati u ladice“ i da bi s učenicima trebali češće provoditi aktivnosti u kojima se traži povezivanje gradiva i ranije stečenih znanja. Prema Vrkić i Vlahović Štetić (2013), uvjerenja o kognitivnim strategijama i uvjerenja o strategijama metakognitivne samoregulacije pokazala su se kao značajni pozitivni prediktori učenja, ali učenici više koriste kognitivne od metakgnitivnih strategija učenja u kojima je prisutno i korištenje postupaka kontrole učenja. Razloge takvog odabira načina učenja Garner (1990) nalazi u činjenici da se učenici ne koriste strategijama učenja višeg reda ako vjeruju da neće uspjeti u učenju, unatoč korištenju takvih strategija pri učenju. Zbog toga je neophodno tijekom nastave potaknuti učenike na učenje uz primjenu grafičkih organizatora znanja, a posebno konceptualnih mapa, koje osiguravaju veću uspješnost u retenciji naučenog (Latin i sur, 2016) te osiguravaju više razine kognitivnog učenja. Korištenje konceptualnih mapa, koje služe kao predložak ili šablona u organizaciji i strukturiranju znanja, olakšava razumijevanje i omogućuju smisleno učenje 
(Novak i Cañas, 2007), odnosno potiče primjenu viših razina kognitivnog učenja. Pri tome je potrebno, tijekom poučavanja, učenicima pokazati kako organizirana i grafički sistematizirana znanja oblikovana na temelju kritičkog promišljanja učenika mogu znatno pomoći u rješavanju problemskih pitanja, posebno ako su ona vezana uz svakodnevni život. Time će učenicima učenje dobiti smisao i svrhu.

Već se u dobi od 11 godina jasno diferenciraju usmjerenja pri savladavanju prirodoslovnih znanja. Učenike koje zanimaju fizička svojstva tla i geografske karakteristike ne zanimaju kemijske i biološke karakteristike tla, ali takvi učenici žele razumjeti prirodu oko sebe uz povezivanje svoga znanja. Uočen je utjecaj specifičnih interesa za povezane teme (npr. za veličine zrnaca u tlu i biljaka koje rastu u tlu), koji rezultira kvalitetnijom pripremom objašnjenja uz pitanja i izraženijoj sklonosti razmišljanju o povezanosti parametra. Učenici koje zanimaju mjerne karakteristike pokazuju izraženu vizualnu orijentaciju pri učenju s razumijevanjem, a oni koji žele sistematizirati svoje znanje uočavaju njihovu primjenjivost u različitim aktivnostima na nastavi.

\section{ZAKLUČAK}

Istraživanje je pokazalo kako su učenici u dobi od 11 godina izrazito zainteresirani za učenje tema vezanih uz Tlo te su učenici koji su slabije riješili ispit, kao i oni učenici koji su ga riješili vrlo uspješno na početku učenja, iskazali jednaku zainteresiranost za učenje o tlu. Usprkos nastavi temeljenoj na praktičnim radovima, i neki najuspješniji učenici smatraju da se u takvim aktivnostima od njih ne traži primjena ranije stečenog znanja iz Prirode. Također, učenici često ne prepoznaju da aktivnosti provedene tijekom učenja i poučavanja mogu poslužiti kao osnova s kojom mogu povezati ranije obrađena znanja. Kao posljedica izostanka osvješćivanja procesa učenja tijekom prethodnog učenja je da su još uvijek i najuspješniji učenici često orijentirani na reproduktivno učenje i imaju problema $s$ rješavanjem zadataka u kojima se traži razmišljanje svojstveno za više kognitivne razine učenja. To se očituje kod zadataka koji traže razumijevanje, pri čemu oni često u svojim odgovorima pokazuju samo prepoznavanje, npr. oni prepoznaju da uzorak zemlje koja ima više prostora među česticama tla propušta više vode, ali ne povezuju veličinu prostora među česticama tla s veličinom čestica. Veliki broj učenika ne odgovara na pitanje u kojem trebaju pokazati konceptualno razumijevanje, a pri tome uspješne odgovore daju srednje uspješni i uspješni učenici, dok najuspješniji učenici ne daju objašnjenje, već se njihov odgovor temelji na ponavljanju činjenične primjene znanja sa nastave. Takva objašnjenja učenika često upućuju da su učenici još uvijek skloni nastavne sadržaje „spremati u ladice“, zbog čega bi s učenicima trebalo češće provoditi aktivnosti u kojima se traži povezivanje gradiva i ranije stečenih znanja te im osvijestiti poveznice znanja koje su ostvarili na taj način. Takva pretpostavka potvrđena je time što su učenici koji intuitivno sistematiziraju gradivo uz namjeru uočavanja povezivanja, prepoznaju primjenu svog znanja u aktivnostima poput projekata. Oni u pravilu imaju visoku intrinzičnu motivaciju za učenje Prirode te se trude biti uspješni na nastavi, čak i ako im se ne sviđa ono što uče. Za razliku od njih, učenici koji rješavaju zadatke reproduktivnog karaktera nisu skloni povezivanju svog znanja i često uče napamet.

\section{METODIČKI ZNAČAJ}

Učenici često ne osvještavaju svoje učenje i sriču jednostavne odgovore koji često nisu tražena objašnjenja. Za potrebe poticanja učenika na razmišljanje, $s$ učenicima se moraju češće provoditi aktivnosti u kojima se traži argumentirano povezivanje stečenog znanja pri generiranju objašnjenja. Potrebno je poticati učenike da nastavnu temu promatraju kao cjelinu koja se nadovezuje $\mathrm{i}$ nadopunjuje, kako bi mogli uistinu razumjeti i primijeniti stečeno znanje. Učenicima slabijih mogućnosti potrebno je pružiti veću pažnju pri izvedbi praktičnog rada i rada na terenu te različitim 
načinima tražiti provjere - ne samo osnovnih činjeničnih znanja, već i barem jednostavnih povezivanja na osnovu kojih bi mogli zaključiti jesu li ostvarili neophodno osnovno razumijevanje. Učenici koji žele razumjeti ono što uče, intuitivno integriraju svoje znanje, jer istovremeno žele povezati znanje jednog područja sa znanjima drugih područja učenja, ali i onim znanjima koja nisu jasno istaknuta kao osnova učenja tijekom poučavanja. To su često učenici koji svjesno primjenjuju znanje tijekom nastave, rade sheme i crtaju dok uče te se trude biti uspješni čak i ako mi se ne sviđa to što uče, zbog čega je pri poučavanju potrebno učenicima nuditi sistematizaciju u obliku grafičkih organizatora znanja te ih poticati na njihovu izradu, kojom će bolje povezati svoje znanje i uvidjeti njegov smisao. Kako bi svi učenici prepoznali primjenu svog znanja u aktivnostima poput projekata, rasprava i praktičnih radova potrebno je pri izradi zadataka za vježbanje i pri sistematizaciji povezati teoretska i praktična znanja koja su usvojili iskustvom i zadacima koje su obavljali tijekom učenja, da bi tako dobili smisao učenja i mogli povezati aktivnosti pri poučavanju s mogućnostima primjene znanja. Pozitivan je uvid da su učenici zainteresirani za istraživanje tla pa to treba biti poticaj za provođenje istraživačkog učenja ili barem praktičnih radova na tu temu koja interdisciplinarno povezuje sve sastavnice biosfere i u njoj se mogu jednostavnim mjerljivim aktivnostima sagledati međuodnosi i utjecaji na cijelu biosferu.

\section{ZAHVALA}

Statistički proračuni izrađeni su korištenjem programskog paketa SPSS 22 (IBM, 2013) susretljivošću djelatnika Centra za istraživanje i razvoj obrazovanja (CIRO) Instituta za društvena istraživanja u Zagrebu (IDIZ), na čemu im se najiskrenije zahvaljujemo.

\section{LITERATURA}

Ablard, K. E., Lipschultz, R. E. (1998). Self-regulated learning in high-achieving students: Relations to advanced reasoning, achievement goals, and gender. Journal of Educational Psychology, 90(1), 94.

Abrahams I. 2009. Does Practical Work Really Motivate? A study of the affective value of practical work in secondary school science, International Journal of Science Education, 31, 17, 2335-2353, DOI: 10.1080/09500690802342836.

Archer, J., Cantwell, R., \& Bourke, S. (1999). Coping at University: an examination of achievement, motivation, selfregulation, confidence, and method of entry. Higher education research \& development, 18(1), 31-54.

Babarović, T., Burušić, J., \& Šakić, M. (2009). Uspješnost predviđanja obrazovnih postignuća učenika osnovnih škola Republike Hrvatske. Društvena istraživanja: časopis za opća društvena pitanja, 18(4-5 (102-103)), 673-695.

Balažinec, M. (2019). Zainteresiranost učenika petih razreda za teme vezane uz istraživanje tla. Educ. biol., 5:68-77. URL DOI: https://doi.org/10.32633/eb.5.5

Begić, V., Bastić, M., Radanović, I. (2016). Utjecaj biološkog znanja učenika na rješavanje zadataka viših kognitivnih razina. Educatio Biologiae, 2: 13-42. Dostupno na: https://hrcak.srce.hr/index.php?show=clanak\&id_clanak_jezik=252569, preuzeto 15.5.2018.

Buljubašić-Kuzmanović, V. (2014). Integrirani kurikulum u funkciji razvoja pedagoških kompetencija. Pedagogijska istraživanja, 11(1), 95-107.

Crooks, T.J. (1988). The Impact Of Classroom Evaluation Practices On Students, Review of Educational Research. 58 (4): 438 481.

Dewey, J. (1916). Nationalizing education. Journal of Education, 84(16), 425-428.

Duncan, T. G., \& McKeachie, W. J. (2005). The making of the motivated strategies for learning questionnaire. Educational psychologist, 40(2), 117-128.

Garner, R. (1990). When children and adults do not use learning strategies: Toward a theory of settings. Review of educational research, 60(4), 517-529.

GLOBE Hrvatska (2010). Priručnik za voditelje programa GLOBE, Priručnik za mjerenja. Dostupno na: https://globe.pomsk.hr/prirucnik.htm, pristupljeno 13.3.2019.

GLOBE Teacher's Guide, Pedosphere (2018). Dostupno na: https://www.globe.gov/do-globe/globe-teachers-guide/soilpedosphere, pristupljeno 13.2.2019.

Golubić, M., Begić, V., Lukša, Ž., Korać, P., Radanović, I. (2017). Razumijevanje životnog ciklusa i oplodnje tijekom učenja biologije u osnovnoj školi. Educatio biologiae, 3(1): 76-99. Dostupno na: https://hrcak.srce.hr/192683, preuzeto 15.5.2018.

Golubić, M., Begić, V., Radanović, I. (2019). Analiza konceptualnih mapa uz udžbenike u svrhu utvrđivanja mogućih konceptualnih poveznica za olakšano razumijevanje procesa razmnožavanja. Educ. biol., 5:48-67. URL DOI: https://doi.org/10.32633/eb.5.4

Hidi, S. (1990). Interest and its contribution as a mental resource for learning. Review of Educational research, 60(4), 549571. 
Hidi, S. (2000). An interest researcher's perspective: The effects of extrinsic and intrinsic factors on motivation. In Intrinsic and extrinsic motivation (pp. 309-339). Academic Press.

Jokić, B., Baranović, B., Hitrec, S., Reškovac, T., Ristić Dedić, Z., Vuk, B., Vuk, R. (2016). Okvir nacionaloga kurikuluma (prijedlog), Cjelovita kurikularna reforma. Dostupno na: http://www.kurikulum.hr/wpcontent/uploads/2016/02/ONK-18.2-POPODNE-2.pdf, preuzeto 29.5.2020.

Juričić Devčić, M., Topolovec, V., \& Mrkonjić, I. (2012). Kognitivni, metakognitivni i motivacijski aspekti rješavanja problema. EDUvision 2012, Modern Approaches to Teaching Coming Generation, 95.

Karakaš, D., Begić, V. (2018). Primjena igre uloga uz elemente izrezane od papira u nastavnoj temi „Najjednostavniji oblici života“. Educ. biol. 4:99-109.

Kitsantas, A., Zimmerman, B. J. (2009). College students' homework and academic achievement: The mediating role of selfregulatory beliefs. Metacognition and Learning, 4(2), 97-110.

Krapp, A. (1999). Interest, motivation and learning: An educational-psychological perspective. European journal of psychology of education, 14(1), 23-40.

Latin, K., Merdić, E., Labak, I. (2016). Usvojenost nastavnog sadržaja iz biologije primjenom konceptualnih mapa kod učenika srednje škole. Educatio Biologiae, 2(2), 1-9.

MZO (2017). Nacionalni dokument Prirodoslovnog područja kurikuluma - prijedlog nakon javne rasprave, Ministarstvo znanosti i obrazovanja, Dostupno na:

https://mzo.gov.hr/UserDocsImages//dokumenti/Obrazovanje/NacionalniKurikulum/PodrucjaKurikuluma//Prirod oslovno\%20podru\%C4\%8Dje.pdf, preuzeto 17.2.2020.

MZO (2019). Kurikulum nastavnog predmeta Biologija za osnovne i srednje škole, Ministarstvo znanosti i obrazovanja, NN 7/19, Dostupno na: https://narodne-novine.nn.hr/clanci/sluzbeni/2019_01_7_149.html, preuzeto 17.1.2020.

Marušić, I., Bizjak Igrec, J., Boban Lipić, A., Labak, I., Milički, J., Šimić Šašić, S., Tot, D., Šabić, J., Ristić Dedić, Z. (2016). Nacionalni kurikulum međupredmetne teme Učiti kako učiti (prijedlog), Cjelovita kurikularna reforma. Dostupno na: http://www.kurikulum.hr/wp-content/uploads/2016/02/UCITI-KAKO-UCITI-FINAL-18.2.pdf, preuzeto 29.5.2020.

NN 7/2019 (2019). Kurikulum međupredmetne teme Učiti kako učiti za osnovne i srednje škole, Ministarstvo znanosti i obrazovanja. Dostupno na: https://narodne-novine.nn.hr/clanci/sluzbeni/2019_01_7_154.html, preuzeto 29.5.2020.

Novak, J. D., Cañas, A. J. (2007). Theoretical origins of concept maps, how to construct them, and uses in education. Reflecting Education, 3(1), 29-42.

Pintrich, P. R. (2004). A conceptual framework for assessing motivation and self-regulated learning in college students. Educational psychology review, 16(4), 385-407.

Pintrich, P. R., \& De Groot, E. V. (1990). Motivational and self-regulated learning components of classroom academic performance. Journal of educational psychology, 82(1), 33.

Program GLOBE - Hrvatska (2020). Upute za provedbu. Program GLOBE - Hrvatska. Dostupno na: http://globe.hr/upute-zaprovedbu/, pristupljeno 16.4.2020.

Radanović, I., Ćurković, N., Bastić, M., Leniček, S., Furlan, Z., Španović, P., Valjak, M. (2010). Kvalitativna analiza ispita provedenih 2008. godine u osnovnim školama, Izvješće o projektu - Biologija, NCVVO, Zagreb. Dostupno na: http://dokumenti.ncvvo.hr/OS/Analiza/bio.pdf, preuzeto 15.5.2020.

Radanović, I., Lukša, Ž., Pongrac Štimac, Z., Garašić, D., Bastić, M., Kapov, S., Kostanić, LJ., Sertić Perić, M., Toljan, M. (2017). Sadržajna i metodološka analiza ispita državne mature iz Biologije u školskoj godini 2015./2016. NCVVO Zagreb 212 str.

Radanović, I., Garašić, D, Lukša, Ž., Ristić-Dedić, Z., Jokić, B., Sertić Perić, M. (2016). Understanding of photosynthesis concepts related to students' age. In. Lavonen J., Juuti K., Lampiselkä J., Uitto A. \& Hahl K. (Eds.), Electronic Proceedings of the ESERA 2015 Conference. Science education research: Engaging learners for a sustainable future, Part Learning science: Conceptual understanding/strand 1(co-ed. Finlayson O. \& Pinto R.), (pp. 271-277). Helsinki, Finland: University of Helsinki. ISBN 978-951-51-1541-6.

Radanović I., Lukša Ž., Pongrac Štimac Z., Garašić D., Bastić M., Kapov S., Kostanić LJ., Sertić Perić M., Toljan M. (2017). Sadržajna i metodološka analiza ispita državne mature iz Biologije u školskoj godini 2015./2016. NCVVO Zagreb 212 str.

Schiefele, U. (1991). Interest, learning, and motivation. Educational psychologist, 26(3-4), 299-323.

Rijavec, M., Raboteg-Šarić, Z., \& Franc, R. (1999). Komponente samoreguliranog učenja i školski uspjeh. Društvena istraživanja, 8(4), 529-541.

Schunk, D. H., Zimmerman, B. J. (Eds.). (1998). Self-regulated learning: From teaching to self-reflective practice. Guilford Press. Dostupno na: https://childtrends.org/wp-content/uploads/2013/05/Child_Trends2003_03_12_PD_PDConfWPK.pdf, preuzeto 15.2.2020.

Šabić, J., Ćurković, N., Buljan Culej, J. (2010). Psihometrijska analiza ispita državne mature, NCVVO, Zagreb. Dostupno na: http://dokumenti.ncvvo.hr/Dokumenti_centra/DM2011/psihometrija_dm_2011.pdf, preuzeto 15.5.2020.

The Program GLOBE (2020). The Program GLOBE. Dostupno na: https://www.globe.gov/, pristupljeno 15.2.2020.

Vrdoljak, G., i Velki, T. (2012). Metakognicija i inteligencija kao prediktori školskog uspjeha. Croatian Journal of Education: Hrvatski časopis za odgoj i obrazovanje, 14(4), 799-815.

Vrkić, M., Vlahović Štetić, V. (2013). Uvjerenja o strategijama učenja, korištenje strategija učenja i uspjeh u studiju. Napredak: Časopis za interdisciplinarna istraživanja u odgoju i obrazovanju, 154(4), 511-526. 
Wolters, C. A., Pintrich, P. R., \& Karabenick, S. A. (2005). Assessing academic self-regulated learning. In What do children need to flourish? (pp. 251-270). Springer, Boston, MA. Dostupno na: https://childtrends.org/wpcontent/uploads/2013/05/Child_Trends-2003_03_12_PD_PDConfWPK.pdf, preuzeto 15.2.2020.

Winne, P. H. (2005). Key Issues in modeling and applying research on self-regulated learning. Applied Psychology, 54(2), 232-238.

Zeidner, M., Shani-Zinovich, I., Matthews, G., Roberts, R. D. (2005). Assessing emotional intelligence in gifted and non-gifted high school students: Outcomes depend on the measure. Intelligence, 33(4), 369-391.

Zidar, L., Begić, V., Bastić, M., Radanović, I. 2018. Razumijevanje koncepata ravnoteže i međuovisnosti kod učenika u dobi od 13 godina. Educ. biol., 4:35-51. https://doi.org/10.32633/eb.4.3

Zimmerman, B. J. (2000). Self-efficacy: An essential motive to learn. Contemporary educational psychology, 25(1), 82-91.

Zimmerman, B. J., Pons, M. M. (1986). Development of a structured interview for assessing student use of self-regulated learning strategies. American educational research journal, 23(4), 614-628.

\section{PRILOZI}

Prilog 1 Anketni upitnik za utvrđivanje interesa učenika uz sadržaj poučavanja (Balažinec, 2019)

\begin{tabular}{|c|c|c|c|c|}
\hline Želim proučavati i istraživati... & $\begin{array}{c}1 \\
\text { Uopće me ne } \\
\text { zanima }\end{array}$ & $\begin{array}{c}2 \\
\text { Ne zanima } \\
\text { me }\end{array}$ & $\stackrel{3}{\text { Zanima me }}$ & $\begin{array}{c}4 \\
\text { Vrlo sam } \\
\text { zainteresiran }\end{array}$ \\
\hline \multicolumn{5}{|l|}{...vrste tla } \\
\hline \multicolumn{5}{|l|}{...propusnost tla } \\
\hline \multicolumn{5}{|l|}{...rahlost tla } \\
\hline \multicolumn{5}{|l|}{...boju tla } \\
\hline \multicolumn{5}{|l|}{...tvrdoću tla } \\
\hline \multicolumn{5}{|l|}{...ljepljivost tla } \\
\hline \multicolumn{5}{|l|}{...ljekovitost tla } \\
\hline \multicolumn{5}{|l|}{...plodnost tla } \\
\hline \multicolumn{5}{|l|}{...temperaturu tla } \\
\hline \multicolumn{5}{|l|}{...veličinu zrnaca u tlu } \\
\hline \multicolumn{5}{|l|}{....životinje koje žive u tlu } \\
\hline \multicolumn{5}{|l|}{...biljke koje rastu u tlu } \\
\hline \multicolumn{5}{|l|}{...nevidljive organizme $\mathrm{u}$ tlu } \\
\hline \multicolumn{5}{|l|}{... kamenje u tlu } \\
\hline \multicolumn{5}{|l|}{...količinu zraka i vode u tlu } \\
\hline \multicolumn{5}{|l|}{...dubinu, visinu i širinu tla } \\
\hline \multicolumn{5}{|l|}{...miris tla } \\
\hline \multicolumn{5}{|l|}{...utjecaj reljefa i klime na tlo } \\
\hline \multicolumn{5}{|l|}{...fosile u tlu } \\
\hline ...posuđe i alate iz davnina koji s & & & & \\
\hline
\end{tabular}

Prilog 2 Anketni upitnik uz strategije učenja koje učenici primjenjuju tijekom učenja Prirode (Balažinec, 2019)

Tvrdnje $\begin{array}{lcc}\begin{array}{l}\text { Uopće se ne } \\ \text { slažem }\end{array} & 2 & 3 \\ \text { Ne slažem se } & \text { Slažem se }\end{array}$

1. Pokušavam povezati gradivo Prirode s drugim predmetima. slažem

2. Znanje iz Prirode puno primjenjujem u aktivnostima kao što su projekti, rasprave i praktični radovi koje radimo na satu.

3. Kada učim Prirodu radim sheme, mape, crteže i tablice uz ono što trebam naučiti.

4. Kada učim Prirodu podcrtavam bitne riječi.

5. Kada učim Prirodu crtam ono što trebam naučiti.

6. Satovi Prirode me potiču da stvorim svoje mišljenje o onom o čemu učimo.

7. Na satovima Prirode raspravljamo o zaključcima i uvažavamo drukčije ideje.

8. Često pored informacija koja dobijem na satu Prirode, tražim i druge izvore

informacija o onom što smo učili.

9. Misli mi često odlutaju na satovima Prirode.

10. Kad učim za pisanu provjeru iz Prirode često si postavljam pitanja da bih bio siguran jesam li dobro naučio.

11. Kad učim Prirodu stalno pokušavam odrediti što mi sve još nije jasno.

12. Kad učim Prirodu uvijek pokušavam otkriti glavnu ideju ili misao.

13. Obično učim na mjestu gdje mogu imati mir.

14. Redovito učim i rješavam zadaće iz Prirode.

15. Rijetko izostajem iz nastave Prirode.

16. Trudim se biti uspješan na Prirodi čak i ako mi se ne sviđa to što učimo.

17. Učim samo ono što je lagano.

18. Često odustanem od učenja Prirode jer sam lijen ili nezainteresiran

19. Često objašnjavam gradivo iz Prirode drugim učenicima iz razreda.

20. Zajednički rješavamo domaće zadaće iz Prirode.

21. Često Prirodu učimo zajedno s učenicima iz razreda.

22. Potrebna mi je pomoć u učenju kod kuće ili dodatni satovi iz Prirode.

23. Kada ne razumijem nešto iz Prirode tražim da mi to drugi učenici objasne.

24. Kada učim Prirodu koristim se različitim izvorima informacija.

25. Za učenje Prirode i kada mi nešto nije jasno najčešće (zaokruži jedan ili više odgovora):

a) koristim knjigu b) koristim bilježnicu c) koristim radnu bilježnicu d) pitam prijatelje u razredu e) pitam učitelja f) pitam roditelje g) koristim internet 


\title{
Influence of student interest and non-stimulated self-regulated learning on the learning outcomes associated to the topic soil structure and properties
}

\author{
Balažinec M. ${ }^{1}$, Radanović.$^{2}$, Sertić Perić M. ${ }^{2}$ \\ ${ }^{1}$ III. Elementary school Varaždin, Trg Ivana Perkovca 35, Varaždin; ORCID: 0000-0001-9762-0668 \\ marina.barisic13@gmail.com \\ ${ }^{2}$ University of Zagreb, Faculty of Science, Department of Biology, Rooseveltov trg 6, Zagreb; \\ ORCID: 0000-0003-3239-0536, ORCID: 0000-0002-4744-7884
}

\begin{abstract}
To successfully master the learning objectives, it is necessary to arouse students' interest in the context of teaching, by choosing appropriate teaching activities. Thereby, the attitude of students towards learning and the way they learn independently after the initial learning in school is also very important. This study focuses on examining the relationship between: (i) students' initial interest in topics related to the Soil unit, (ii) learning strategies used by students during learning, and (iii) success in the written exam conducted at the end of the Soil unit. The study was conducted in two departments of the fifth grade in the III. Elementary school Varaždin with 43 students. The research showed that 11-year-old students are extremely interested in learning about soilrelated topics. Students who had low success in the written exam, as well as those who excelled at the exam at the beginning of learning, showed equal interest in learning about soil. Students who intuitively systematize the learning material to notice connections, recognize the application of their knowledge in activities such as projects and have a high intrinsic motivation to learn Nature and strive to be successful in learning, even if they do not like what they learn. In contrast, students who successfully solve only reproductive tasks, do not tend to connect their knowledge and often learn by heart. Also, students focused on reproductive learning do not recognize that activities carried out during teaching and learning can serve as a basis for relating previously processed knowledge. To encourage students to think and self-regulate learning, students should be frequently exposed to opportunities to argue the acquired knowledge in generating explanations.
\end{abstract}

Keywords: student interest; self-regulated learning; learning of soil topics; soil structure and properties 